\title{
$v-r 9$
}

\section{تعبيبن راهبردهاى ارتقاء بهرهورى قورى

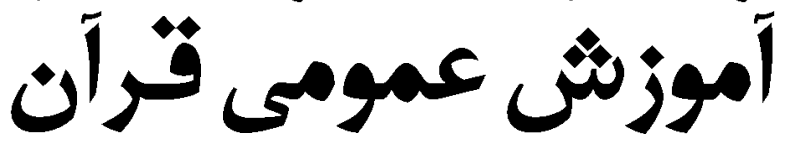

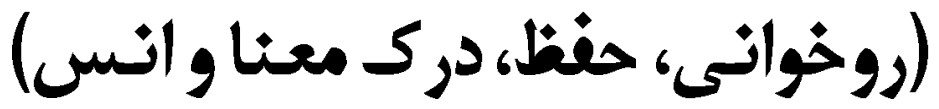

مهدى فيض

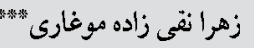

زهرا فيضىى:"

ليلا خسروى مراد"

Oरिक्षि

قر آن كاملترين و بجتترين برنامدُ زندكى براى انسانهايى است كه همواره بـ به دنبال آموختن

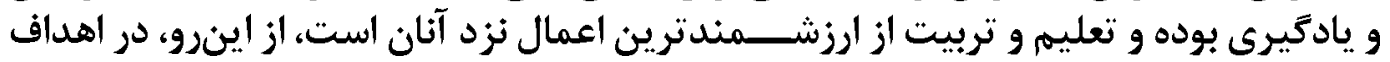

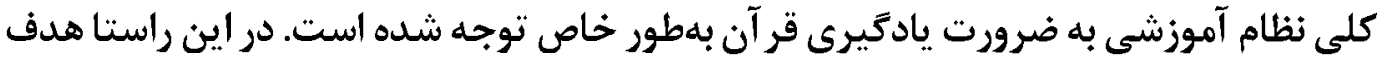

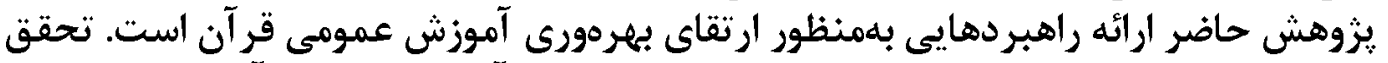

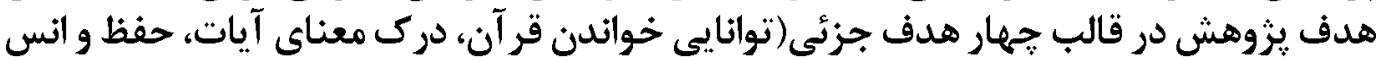

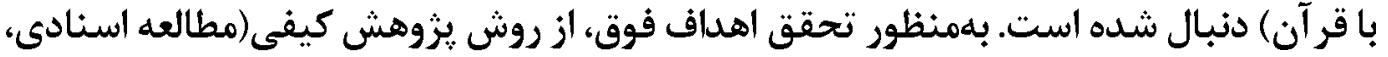

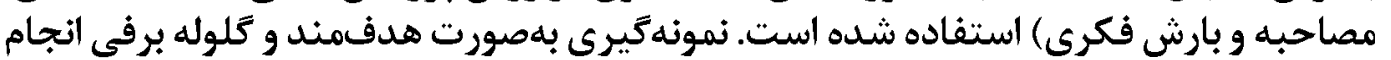

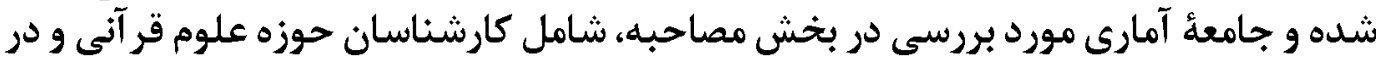

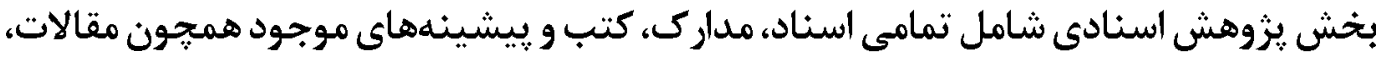

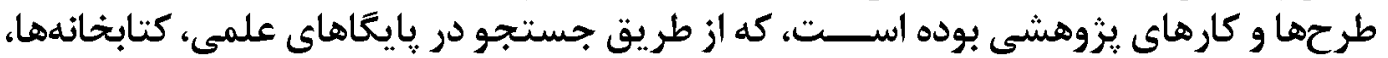

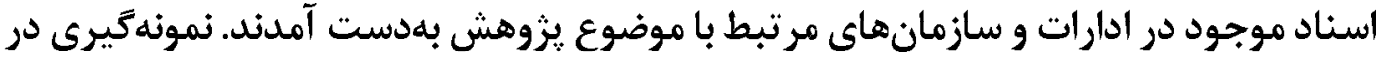

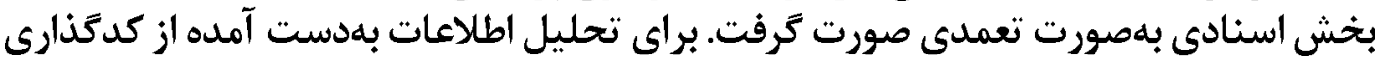

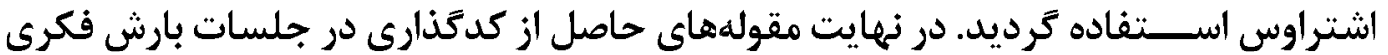

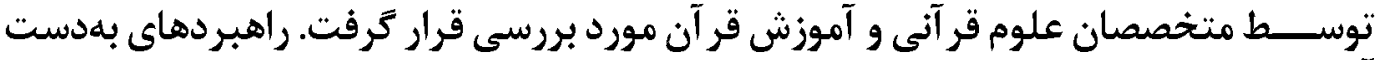

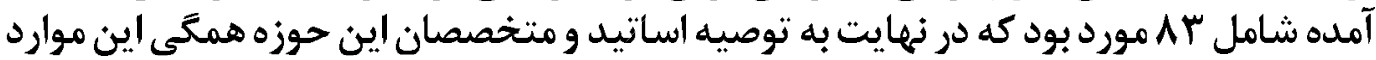

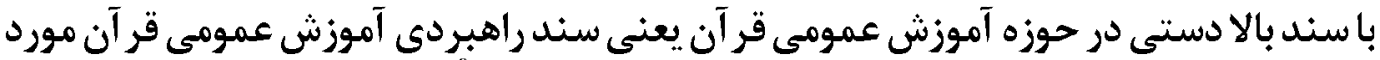

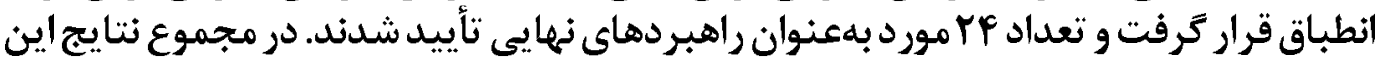

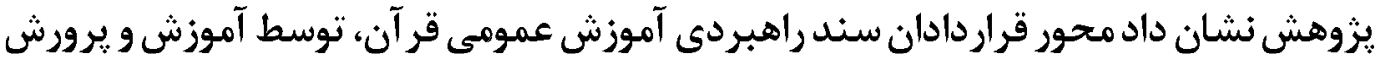

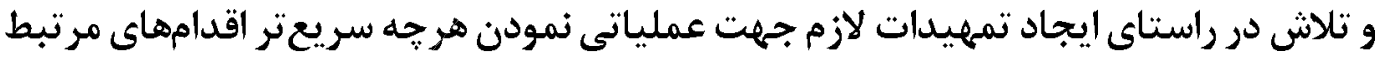

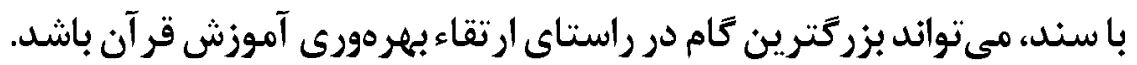

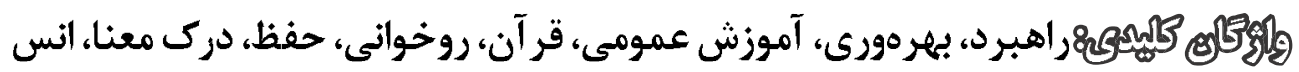




\section{مقدمه}

قــر آن يـيام روشـن الهمى اسـت كه همــه را به راستى و رستخارى دعوت مى كند.

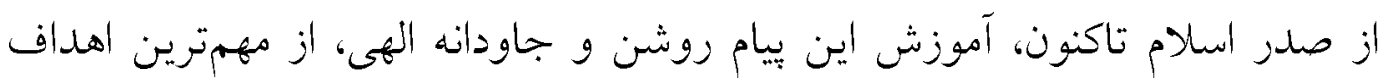

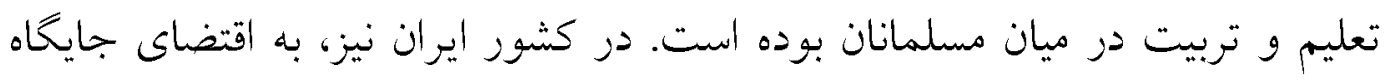

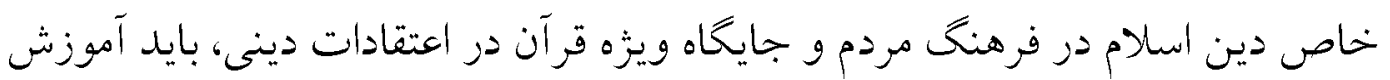

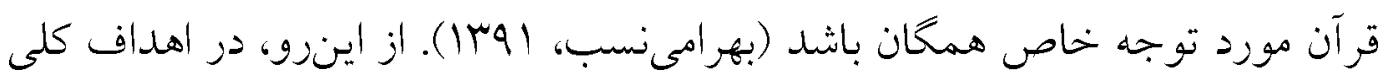

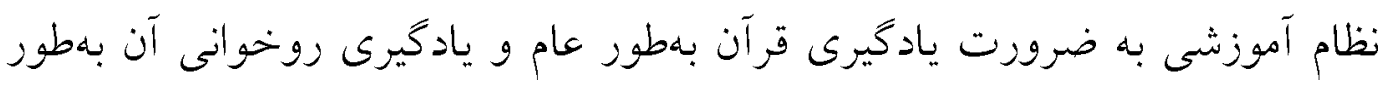

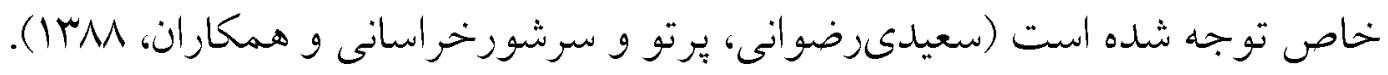

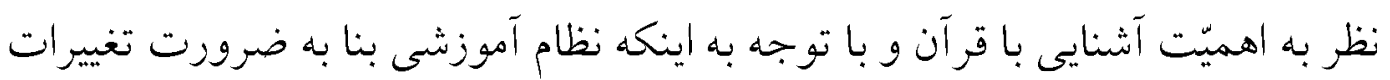

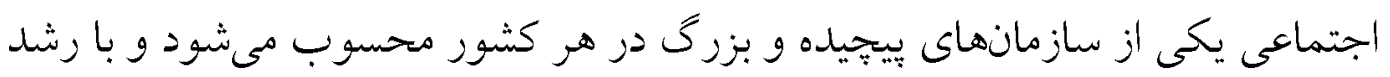

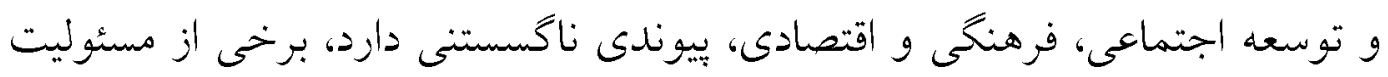

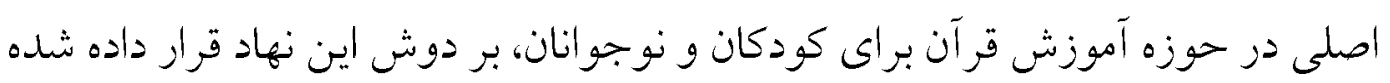

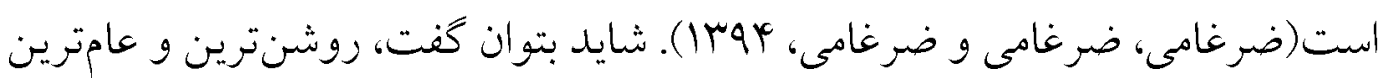

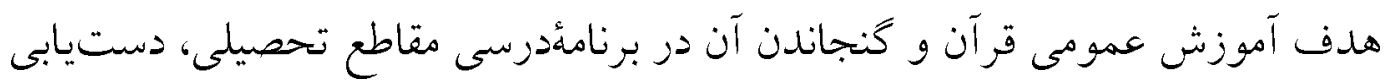

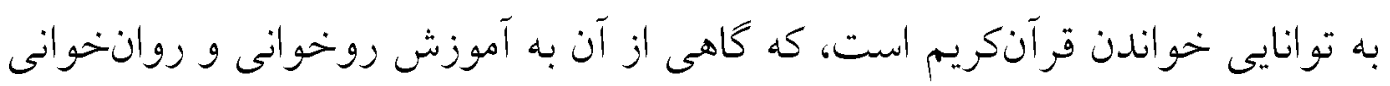

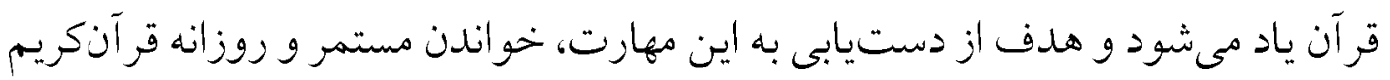

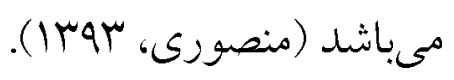

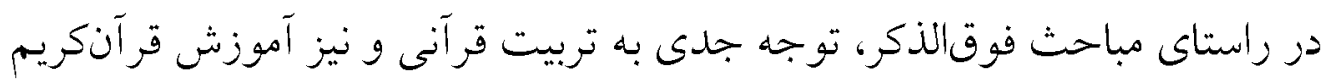

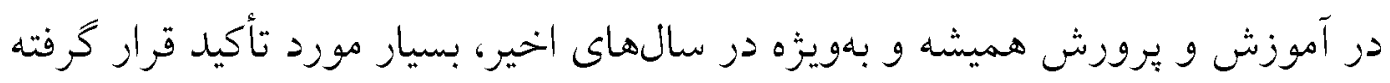

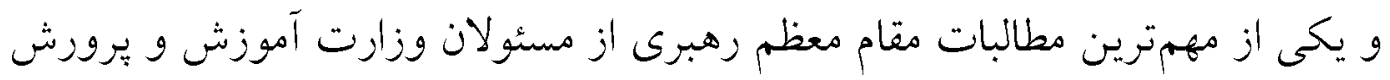

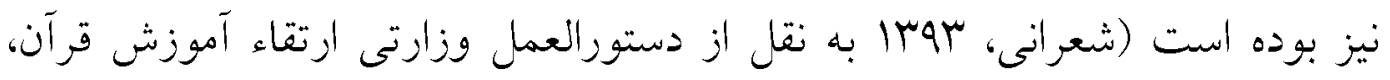

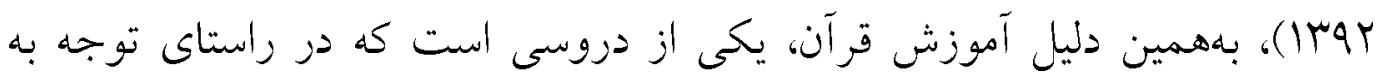

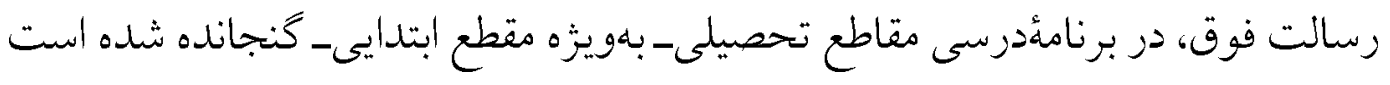

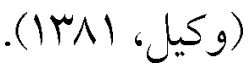
براى رسيدن بـه ايسن مـنظوز بايسـا در خـصوص هريك از اهداف به قابليتها،

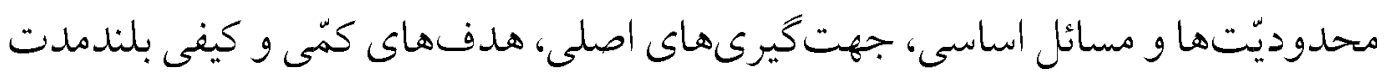

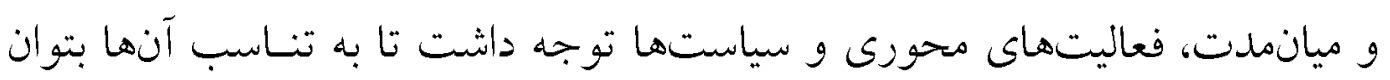


تعيين راهبردهائ ارتقاء بهرهورى آموزش عمومى تمر آن

(روخوانى، حفظ، درك معنا و أنس)

$\mathrm{V}-\mathrm{rg}$

9 اقدامات مهم محورى و فعاليتهاى اولويتدار را انجام داد، و اين بدان معناست كه

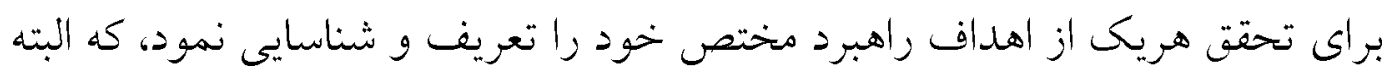

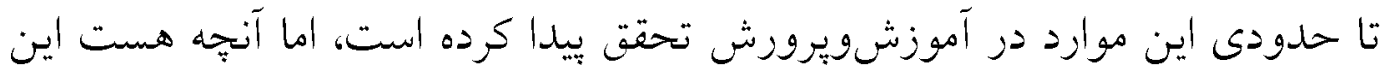

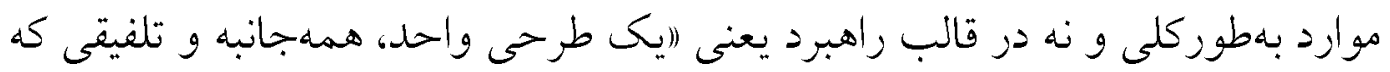

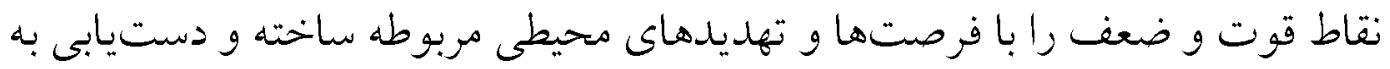

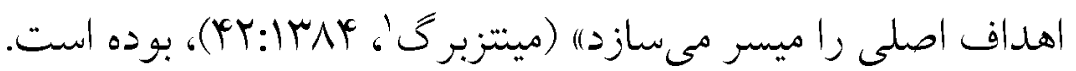

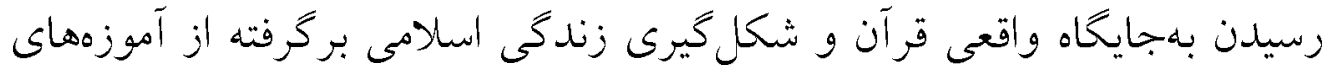

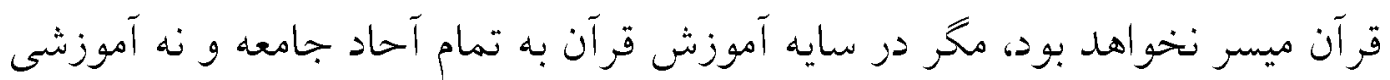

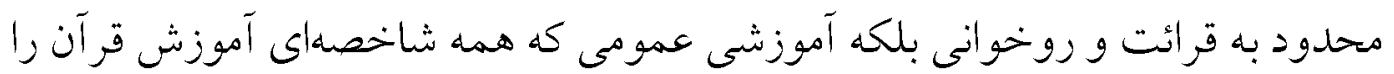

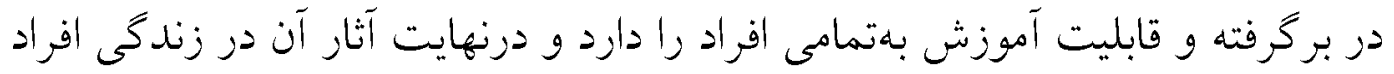

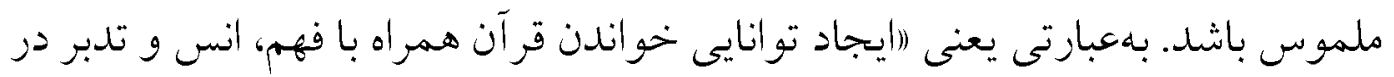

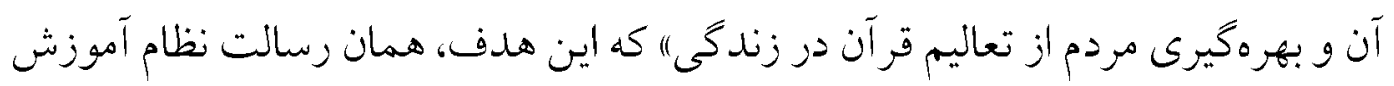

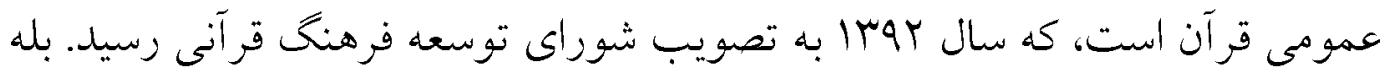

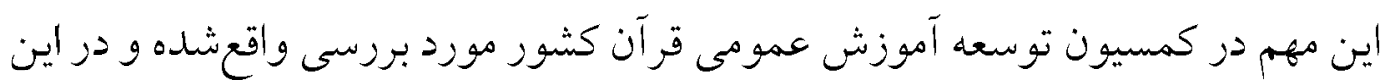

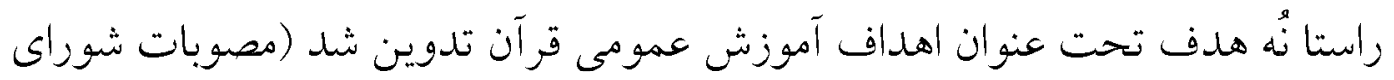

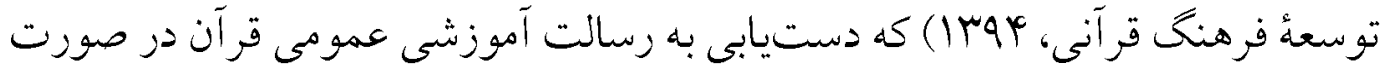

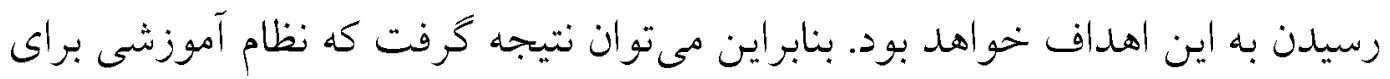

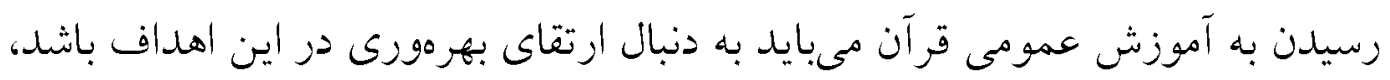

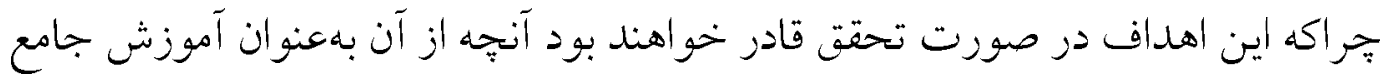

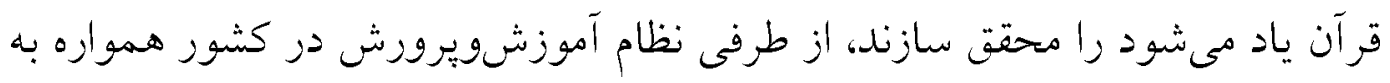

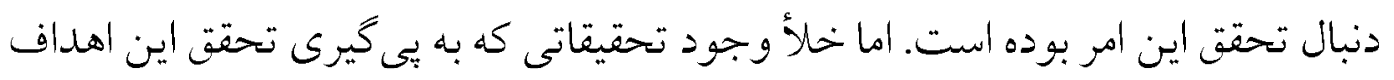

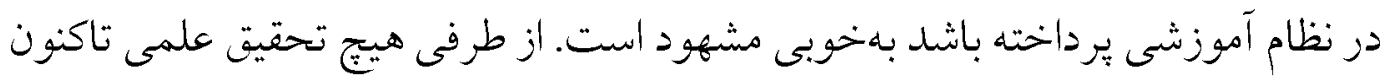

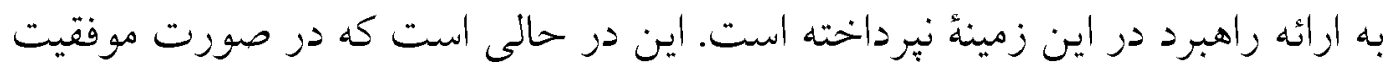

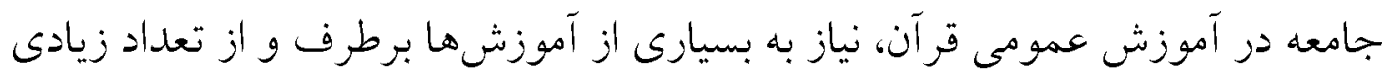

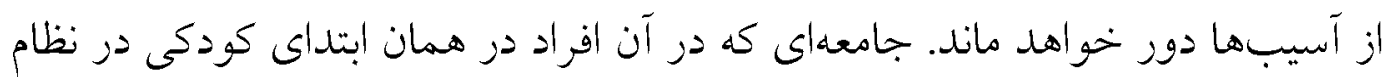




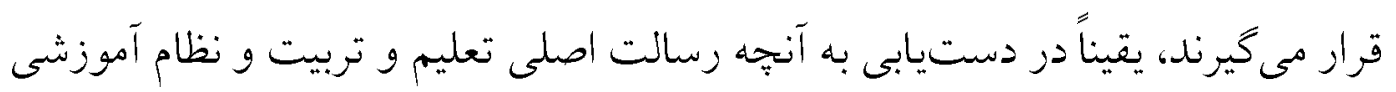

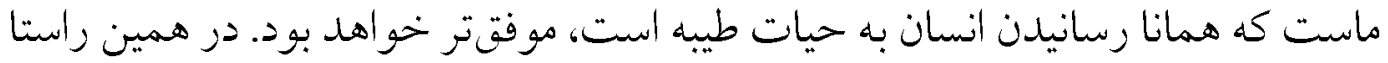

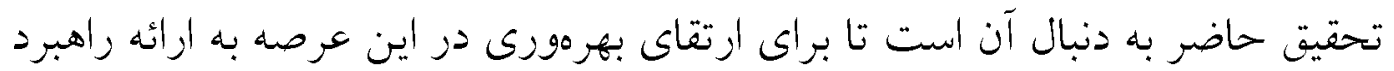
حر جهار هدف (روخوانى، حفظ، درك معنا و انس) بير دازد.

\section{اهداف آموزش عمومى قرآن}

لز يى تصويب منشور توسعه فرهنگ قر آنى و لزوم آموزش عمومى قرآ آن كشور،

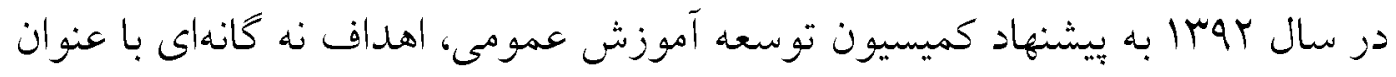
اهداف آموزش عمومى قرآن كشوز به تصويب رسيد. اين اهداف نه كانه كانه شامل:

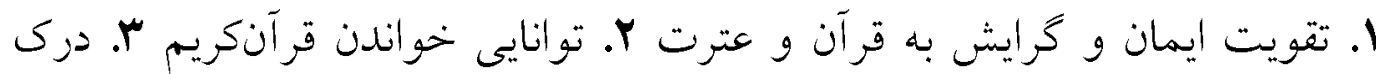

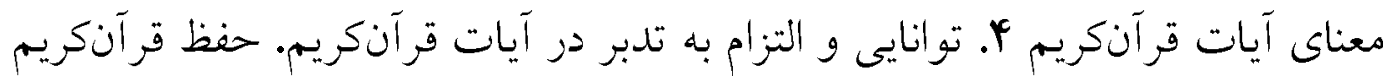

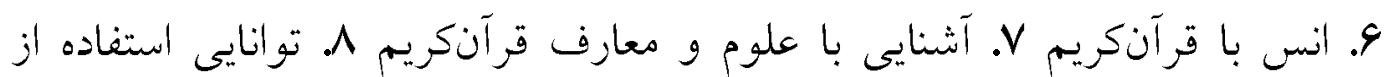

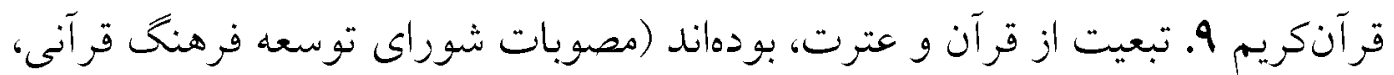

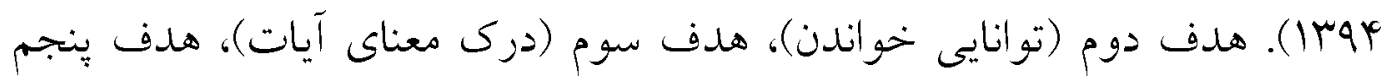

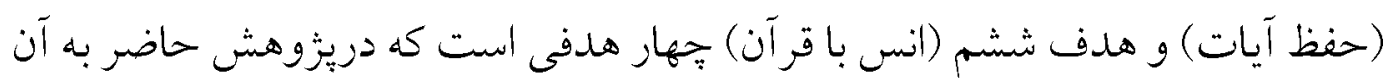

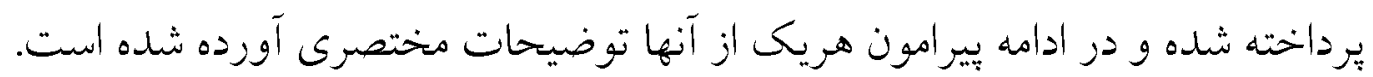

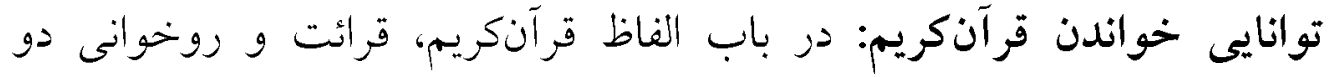

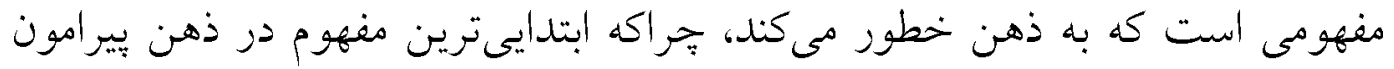

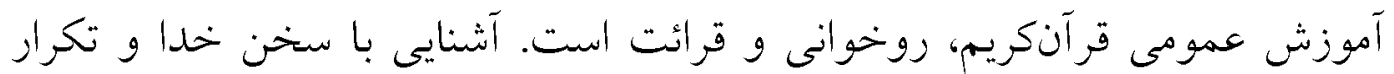

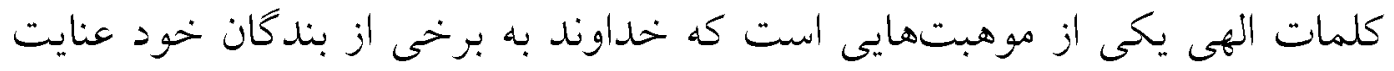

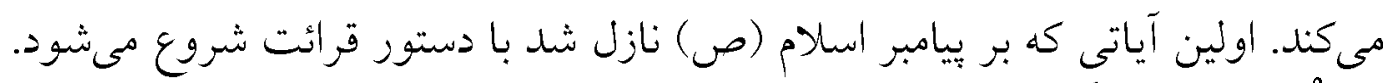

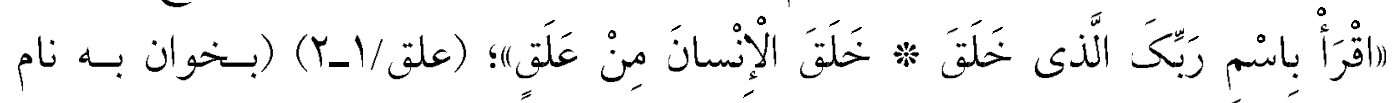

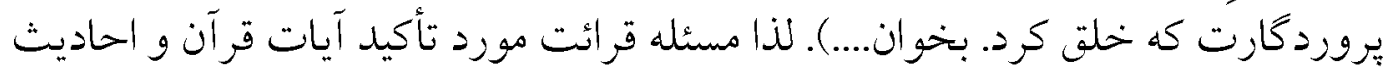

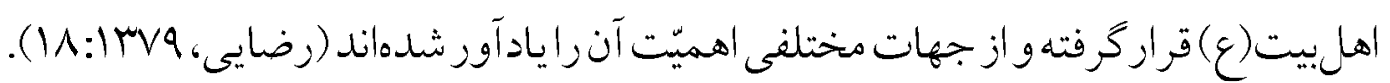

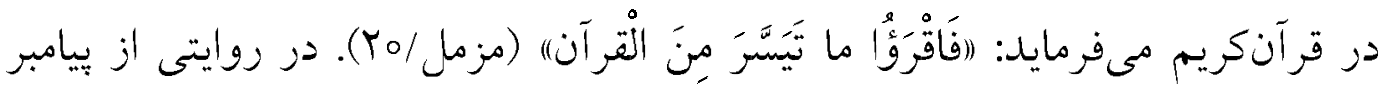

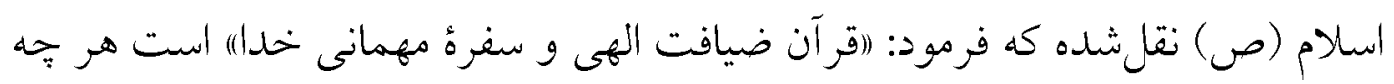

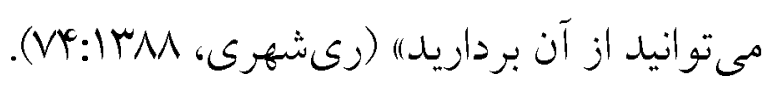


تعيين راهبردهائ ارتقاء بهرهورى آموزش عمومى تمر آن

(روخوانى، حفظ، درك معنا و أنس)

$\mathrm{r}-\mathrm{rg}$

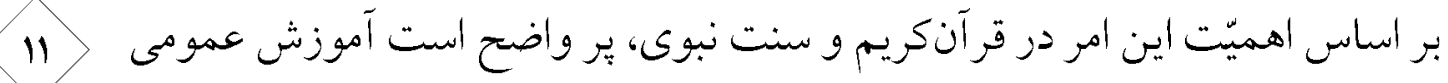

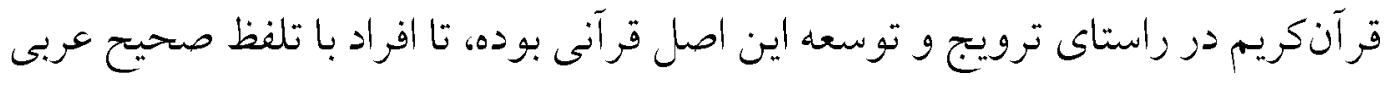

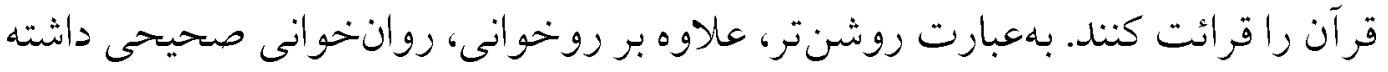

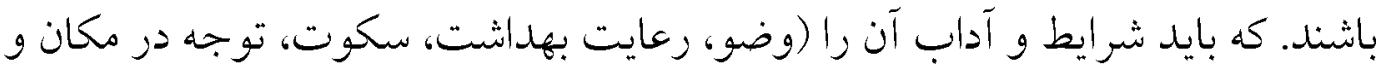

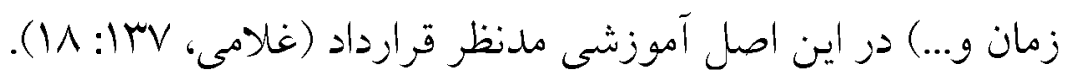

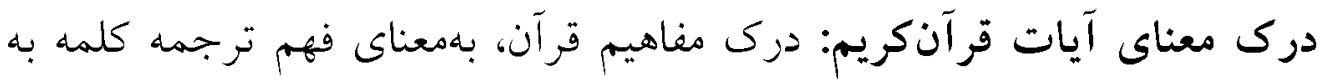

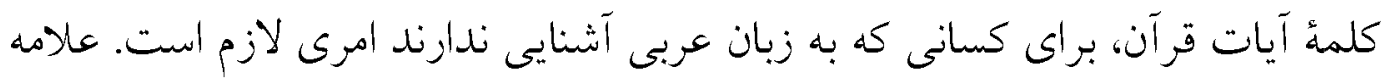

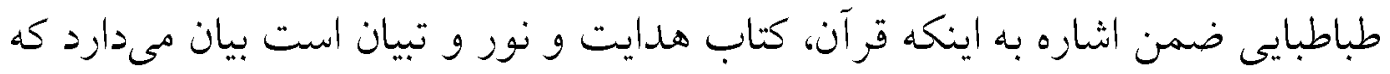

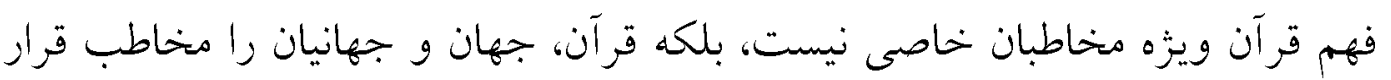

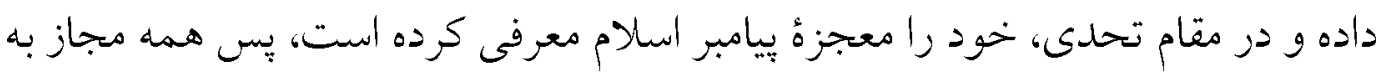

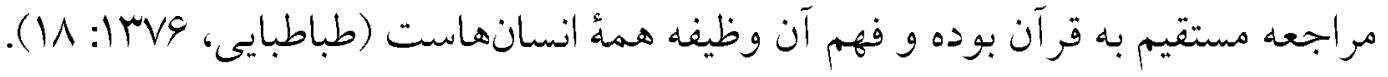

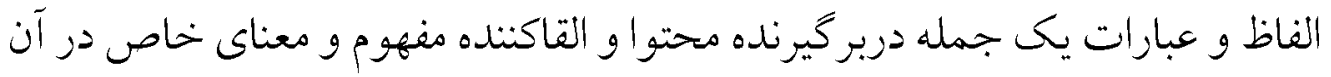

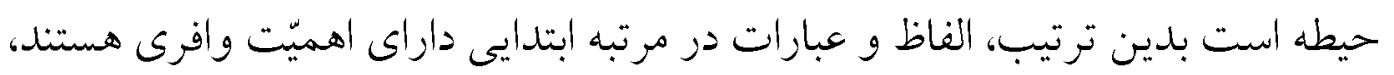

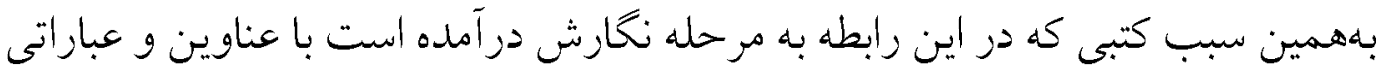

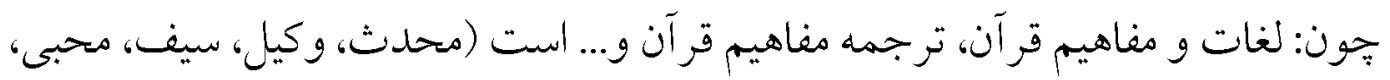

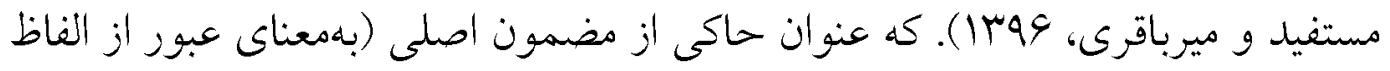

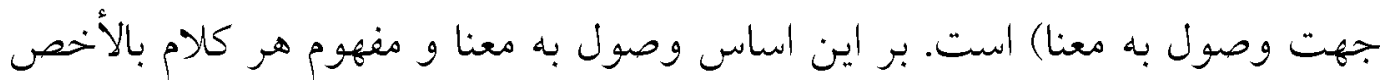

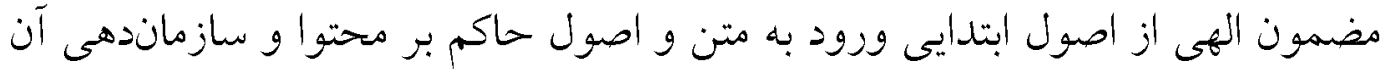

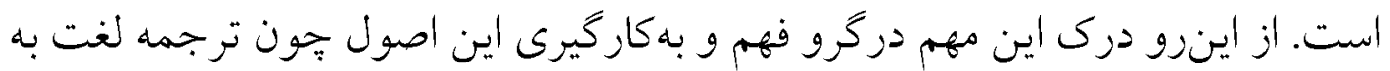

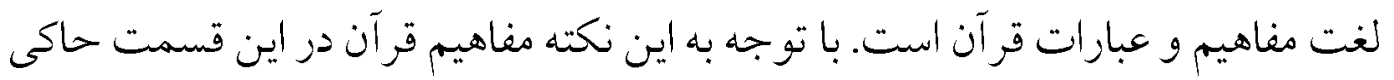
از ازتباط لفظ بامعنا براى القاى يكى مفهوم است.

حفظ قرآنكريم: هدف ديخر در آموزش عمومى قرآن عبارت از توانايى و امكان

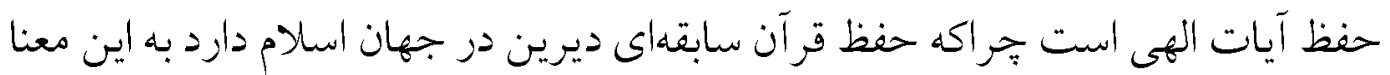

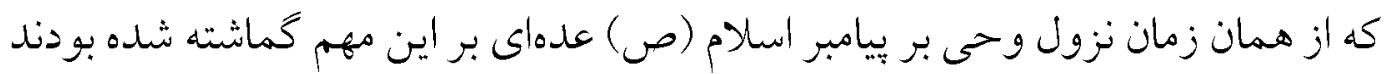

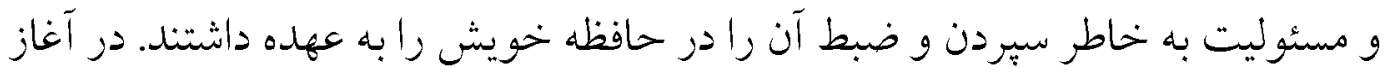

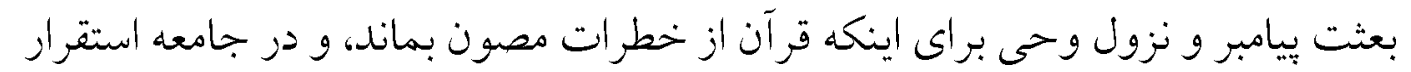

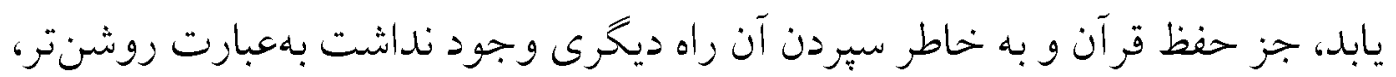


حفظ قرآن فقط به خاطر جلو گيرى از تحريف و نابودى نيست، بلكه دلايل ديخرى

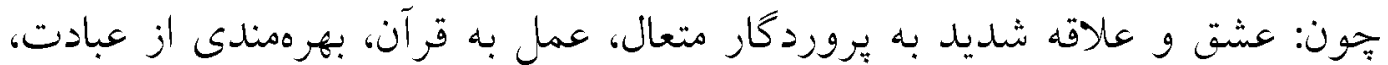

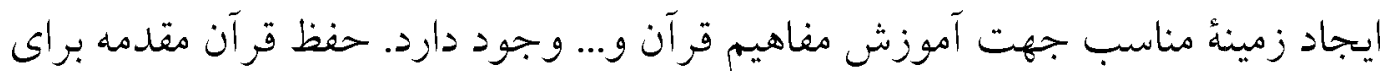

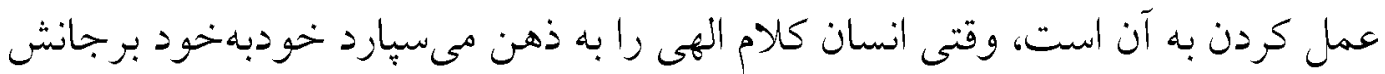

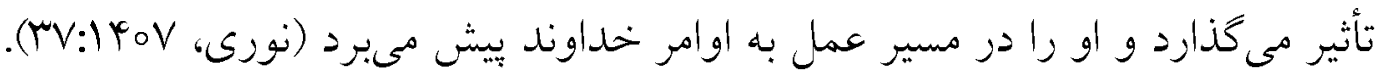

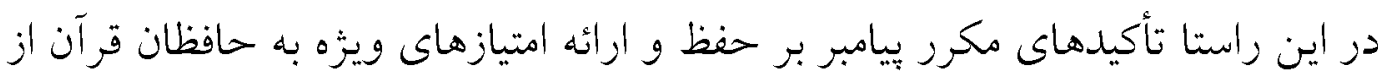

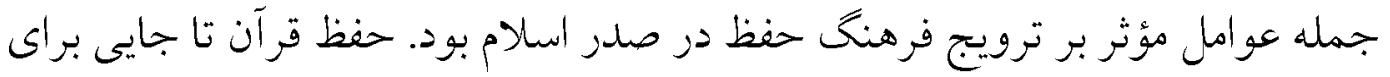

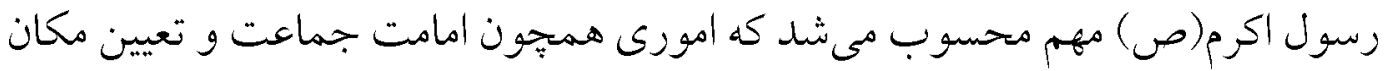

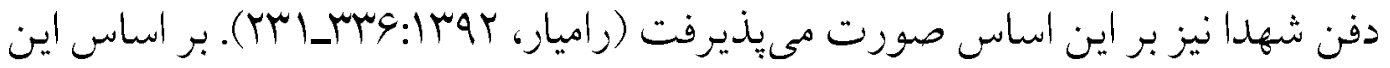

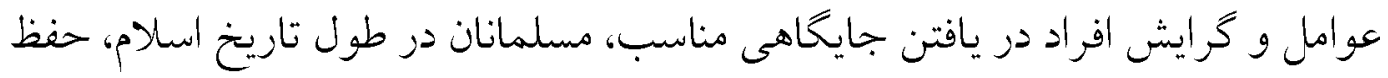

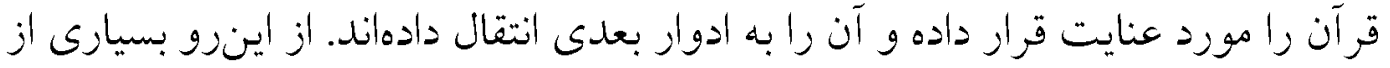

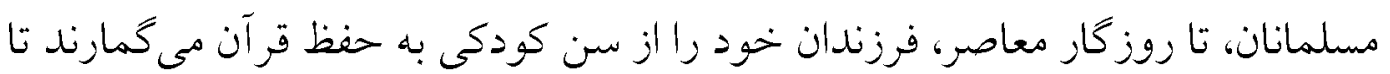

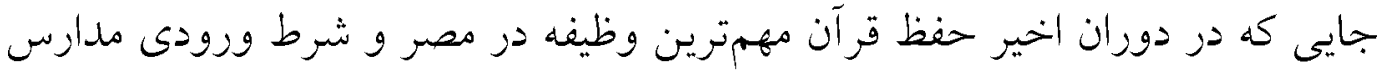

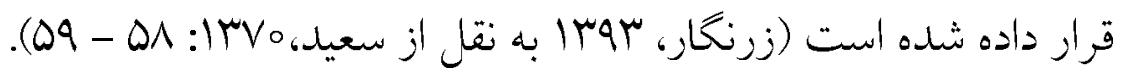
انس با قر آنكريم: انس حر لغت بهمعناى بروز و ظهور است و كسى كه در برابر

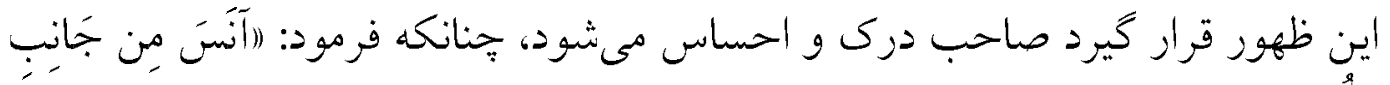

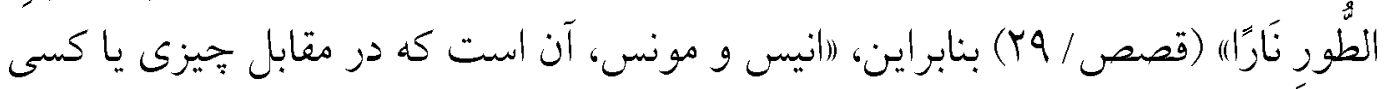
حضوز و ظهور مستمر يا زياد حاشته باشد. دز كاربرد بعلى وازه انس حز مقابل نفرت و

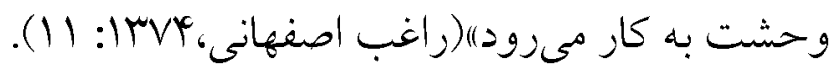

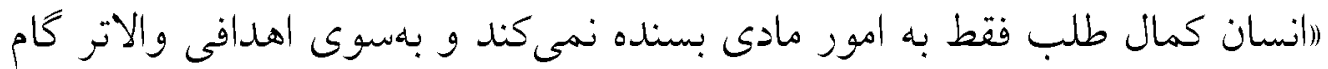

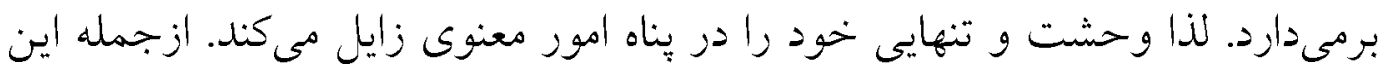

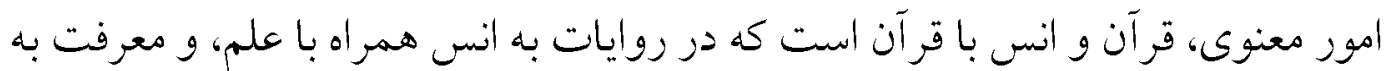

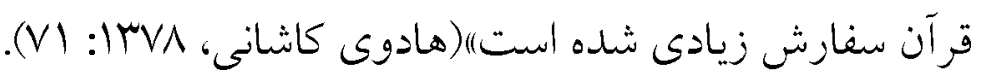
انس رامىتوان در حو نظام طولى و عرضى موزد بررسى قراز داد، به اين معنا كه در

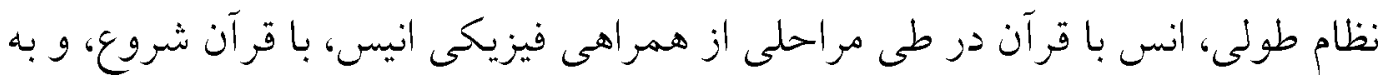

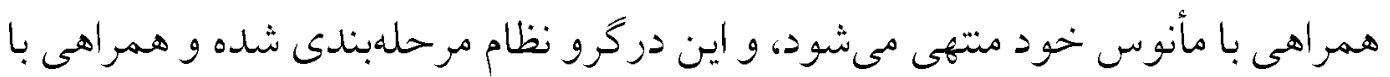

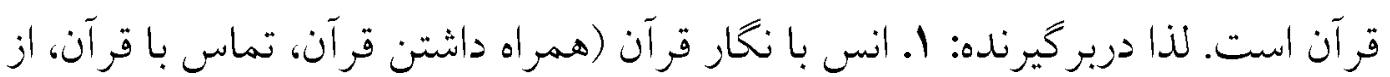


تعيين راهبردهائ ارتقاء بهرهورى آموزش عمومى تمر آن

(روخوانى، حفظ، درك معنا و آنس)

$\mathrm{r}-\mathrm{rq}$

قبيل: دست كشيدن بر قرآن، بر سروصورت نهادن و به كردن آويختن آن، نوشتن قرآن)

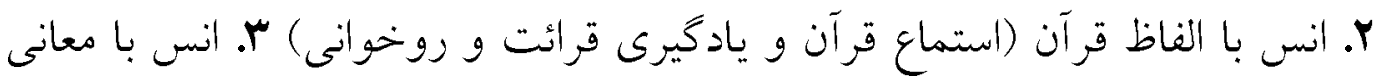

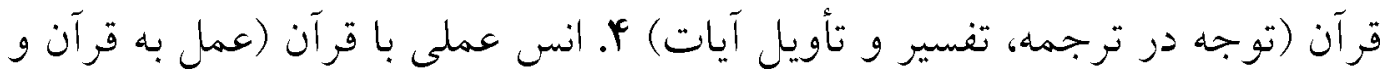

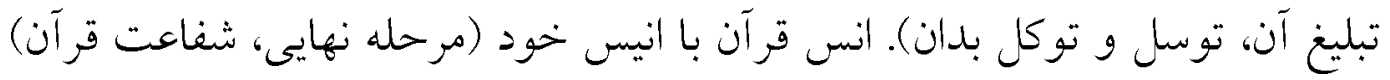

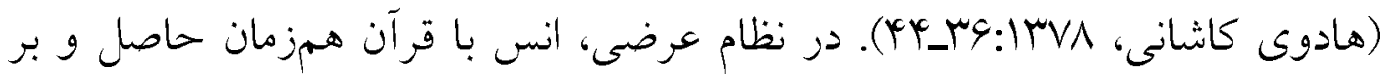

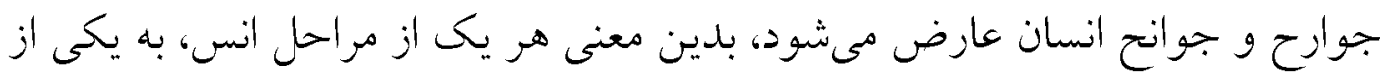

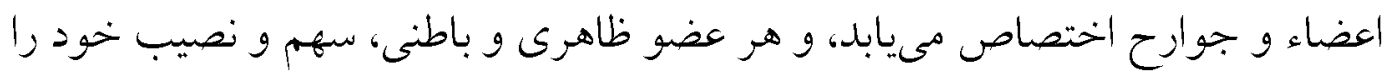

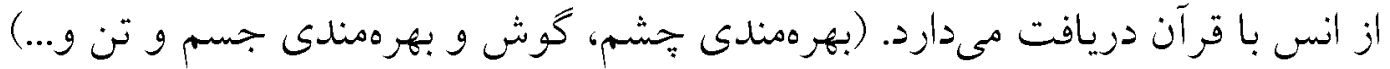

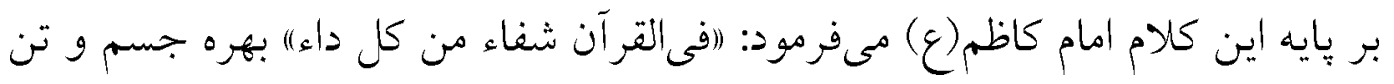

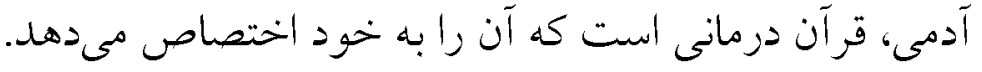

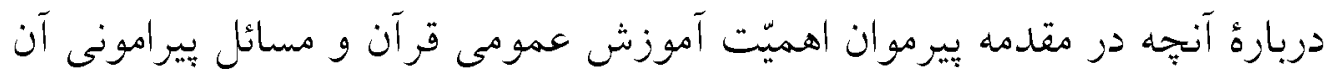

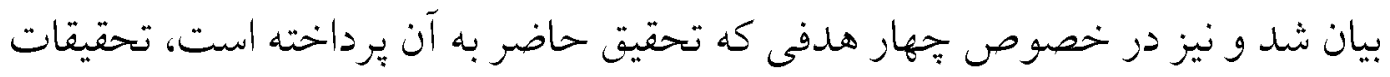

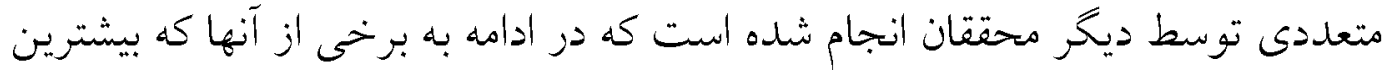

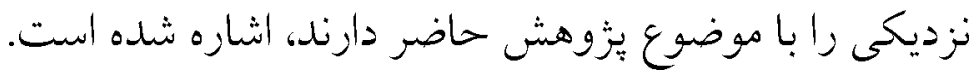

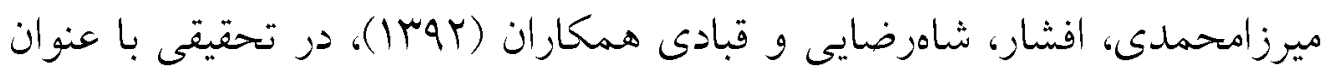

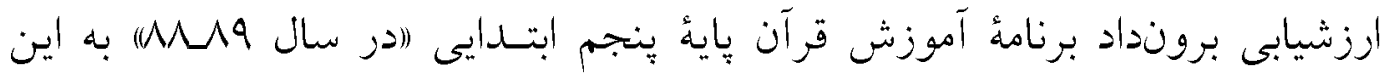

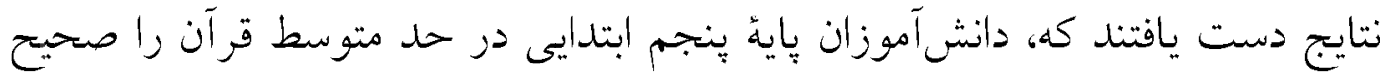

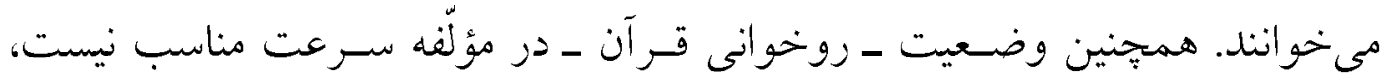

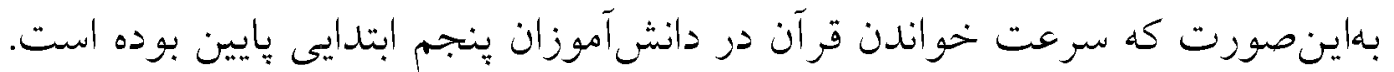

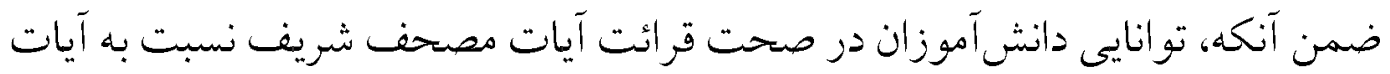

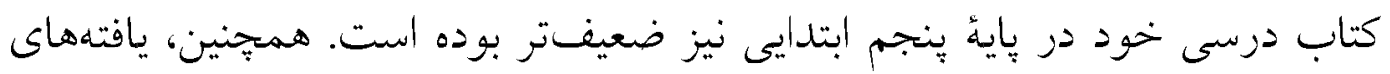

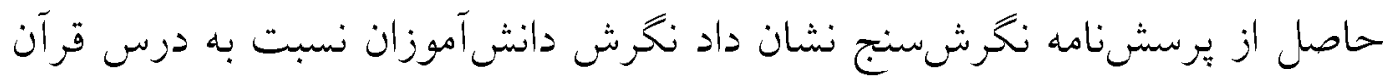

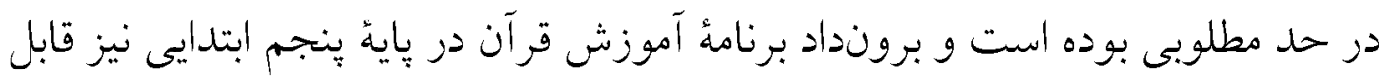

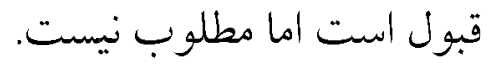

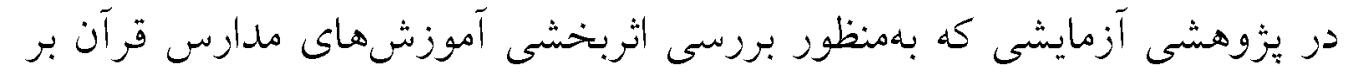

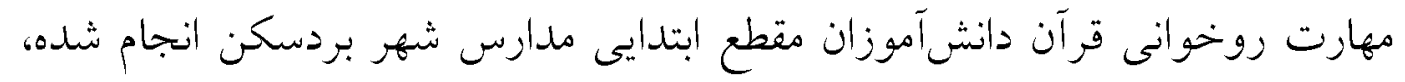

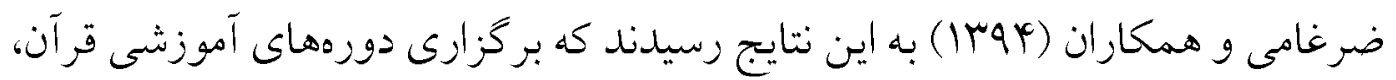


تأثير مهمى بر مهارت روخوانى دانشآموزان ابتدايى مى كذارد. ضمن آنكه، مشخص

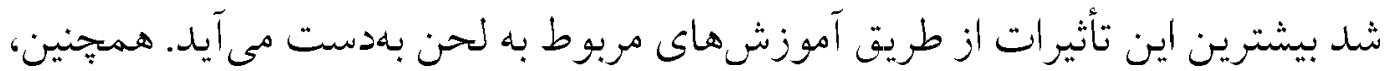

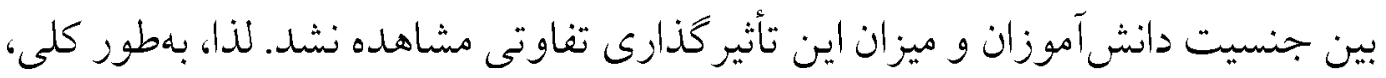

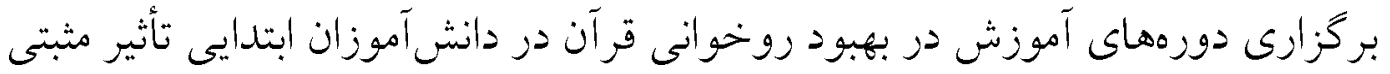

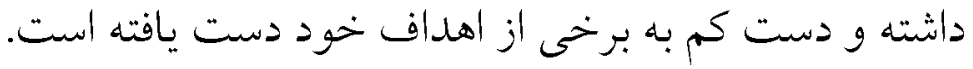

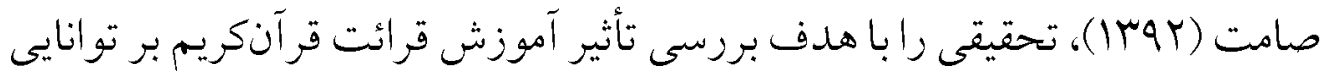

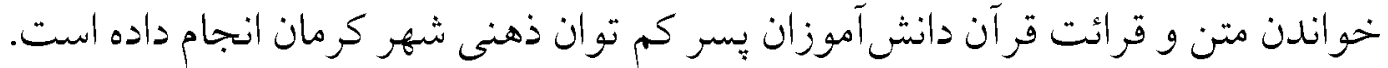

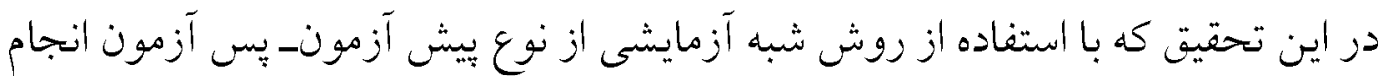

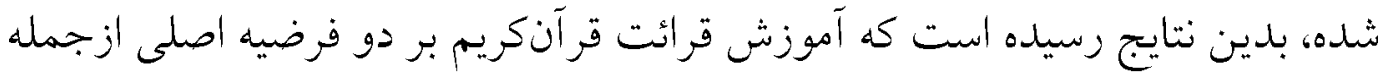

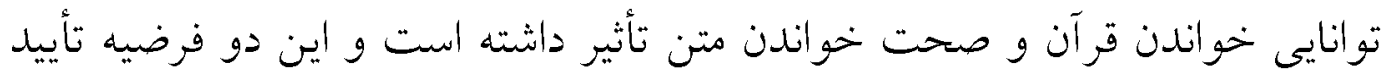

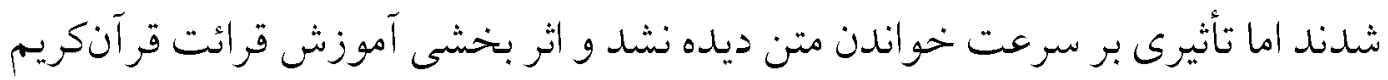

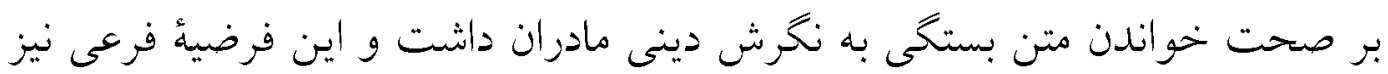
تأييد شد.

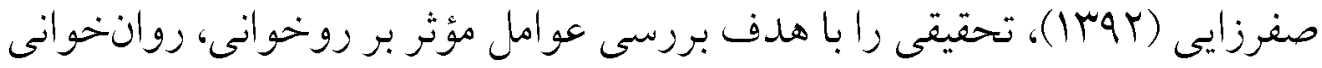

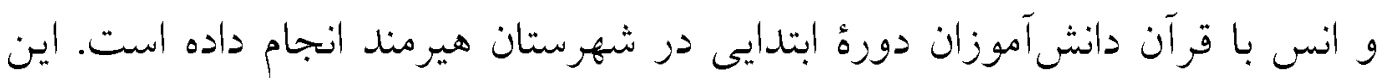

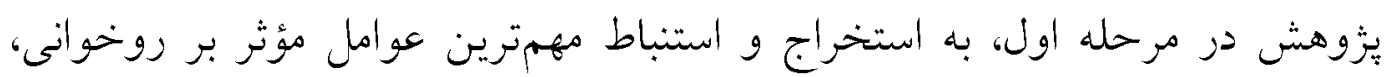

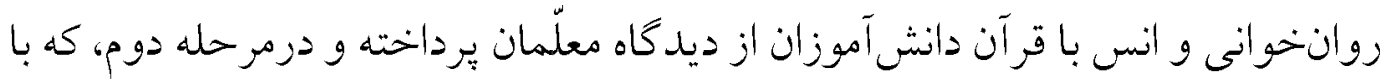

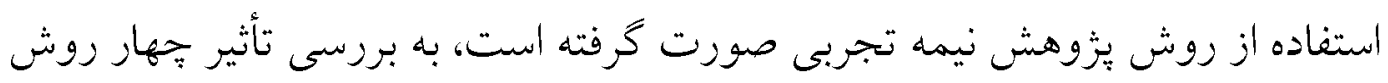

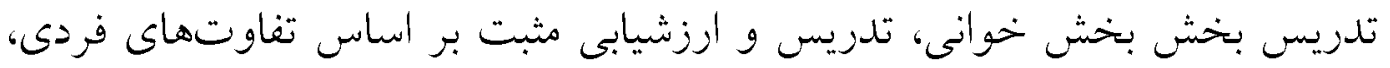

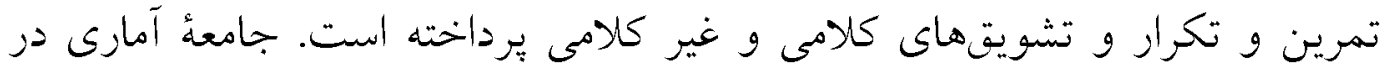

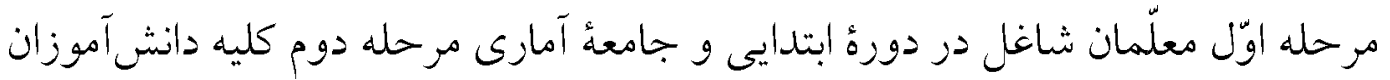

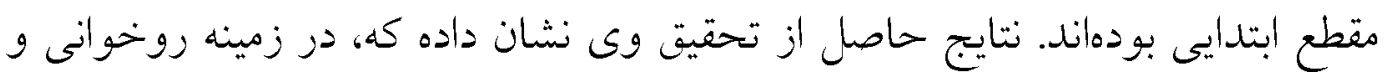

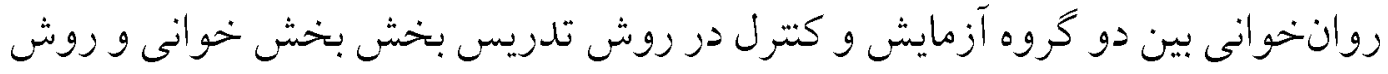

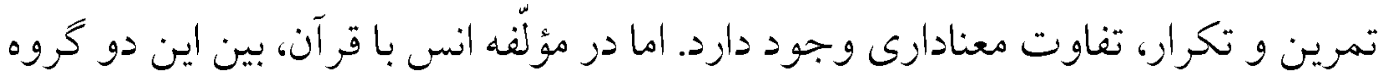

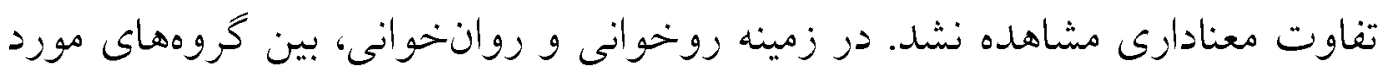

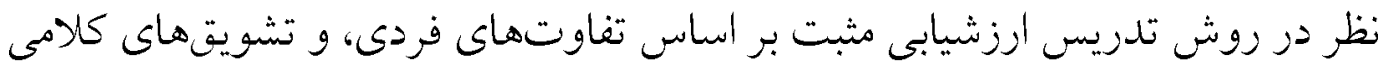

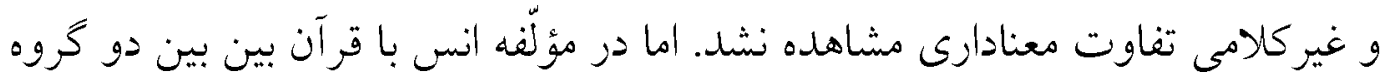


تعيين راهبردهايى ارتقاء بهرهورى آموزش عمومى تمر آن

(روخوانى، حفظ، درك معنا و أنس) آمر آن

$\mathrm{r}-\mathrm{rq}$

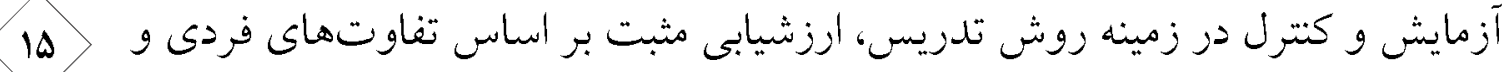
تشويقهاى كالمى و غير كالمى تفاوت مشاهلده شده معنادار بوخه است.

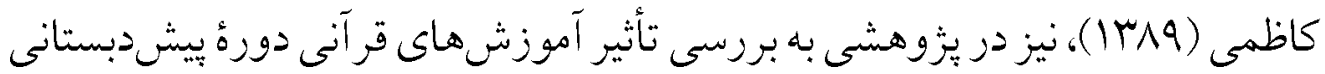
بر مهارت خواندن دانشآموزان يسر اوّل ابتدايى شهر برغسكن (خراسان رضوى)

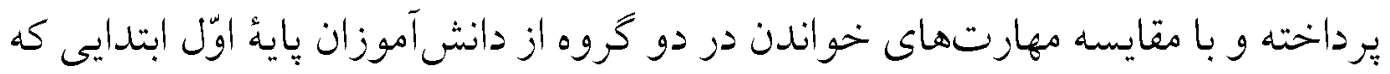
تجربههاى جداكانه در آموزش قرآن در دورة يِيش دبستانى داشتهاند، به بررسى بياملهاى حورة آموزش خواندن قرآن بر مهارت خواندن آنان در كلاس اوّل ابتدايى اقدام نموده است. نتايج آزمون سه فرضيه تحقيت شامل اـ آموزشهاى قرآنى در افزايش مهارت

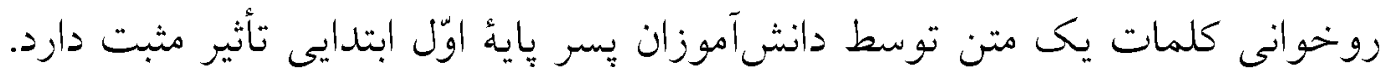
r. آموزش هاى قر آتى در افزايش مهارت زووان خوانى كلمات يكى متن توسط دانش آموزان يسر يايةٌ اوّل ابتدايى تأثير مثبت دارد و ب. آموزشهاي قرآنى در افزايش توانايى تِاسخ به سؤالهاى مطرح شده از محتواى متن خوانده شده توسط دانش آموزان يسر يايهُ اوّل ابتدايى تأثير مثبت دارد، نشان داد كه بين هيجيك از موارد ذكر شده در فرضيهها تفاوت معنادارى وجود نلهاشت.

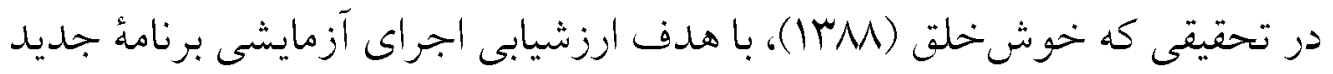
قر آن در دانش آموزان يايه سوم ابتدايى انجام داد، نتايج نشان داد كه علىزغم نكرانى هاى موجود، بين عملكرد تحصيلى دانش آموزان يايه سوم مشمول طرح و غيرمشمول طرح حر دروس فارسى، علوم و رياضيات تفاوت معنادارى وجود ندارد. دانش آموزان مشمول مانند غيرمشمول از لحاظ عاطفى با قرآن انس داشتند. با اجراى برنامه در طول سال

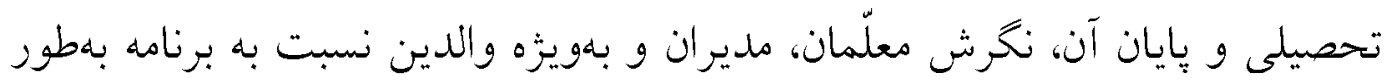

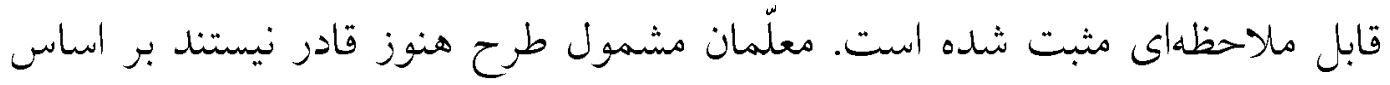
بيشيينىهاى بهعمل آمله زوخوانى را به دانش آموزان ياد دهند. علىزغم برترى نسبى دانش آموزان مشمول طرح دز روخوانى قرآن با مقايسه با غيرمشمولان آنان هنوز در شمرده خهواندن قرآن به حد متوسط نرسيدهاند.

سعيدىرضوانى و همكاران (INMN)، نيز طى يزوهشى به ارزشيابى برونداد برنامهُ آموزش قر آن يايةٌ ينجم ابتدايى يرداخته است. هلف ائن تحقيق برزسى وضعيت توانيى دانش آموزان يايةٌ ينجم ابتلايى دز صحت و سرعت روخوانى قرآن و با استفاده از روش 
بيمايش بوحه است. نتايج اين تحقيق نشان داد عملكرد دانشآموزان دو زبانه (يعنى

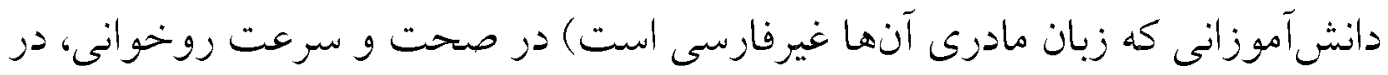

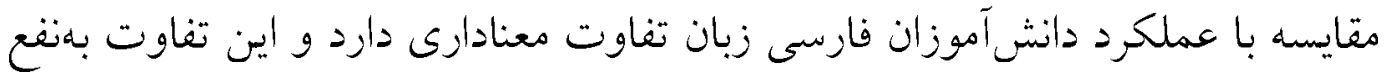

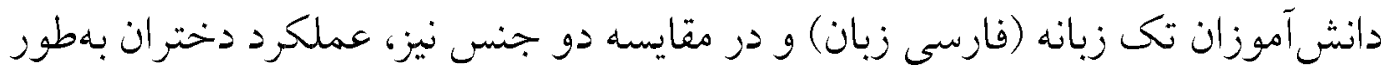

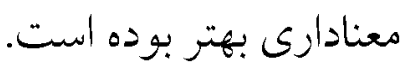

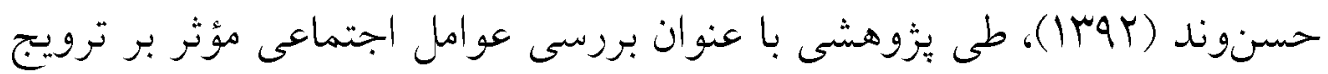

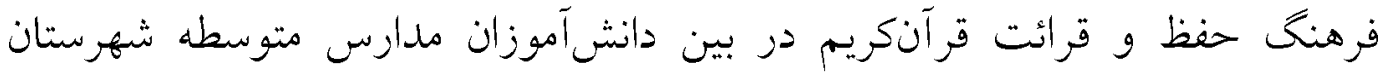

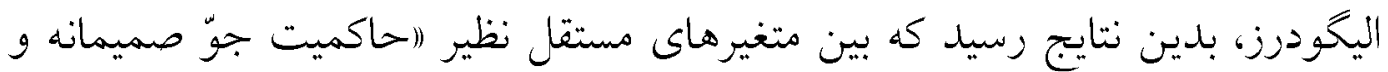

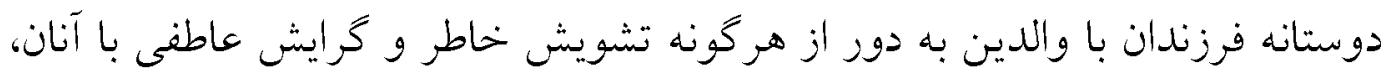

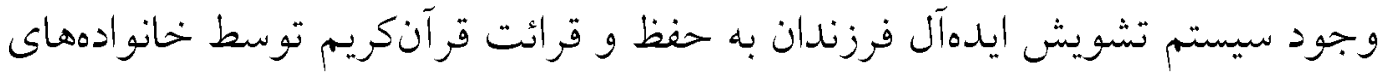

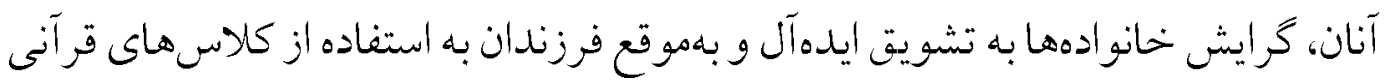

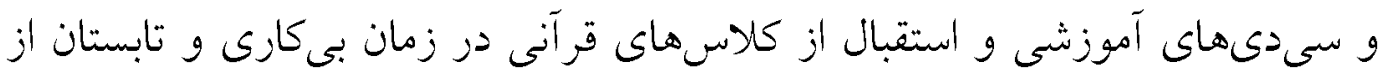

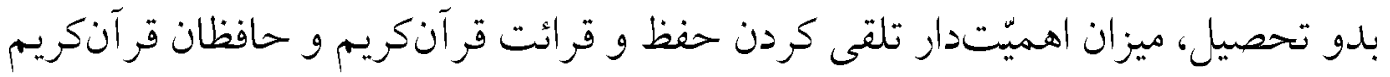

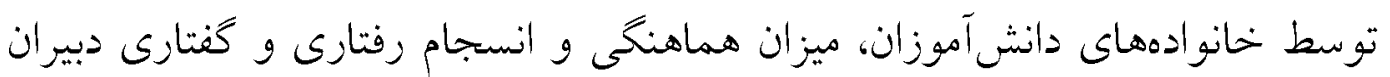

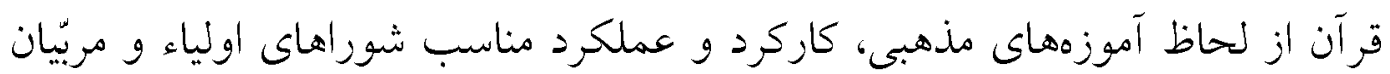

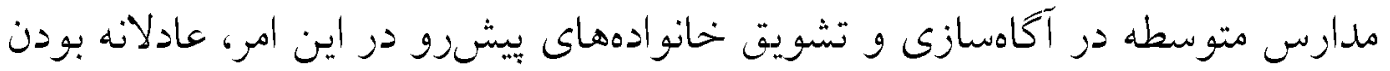

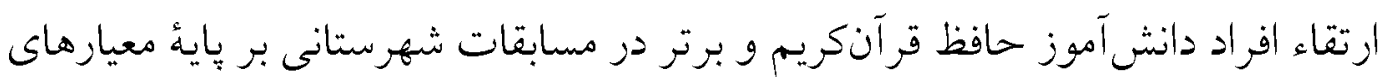

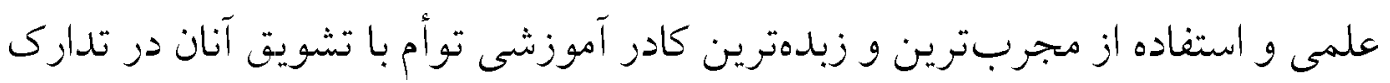

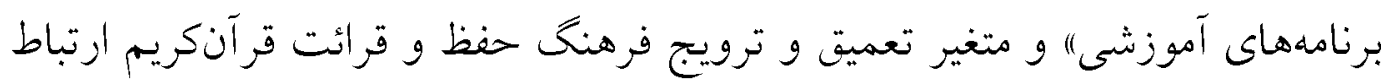
وجود دارد.

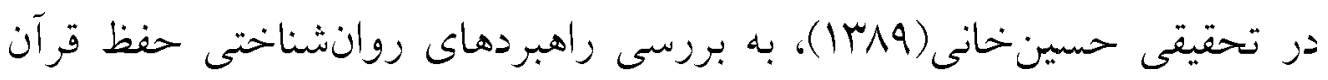

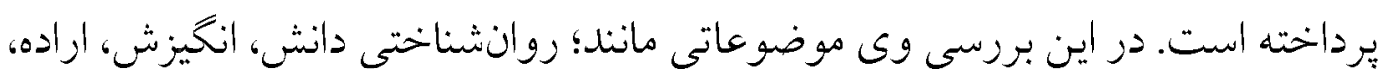

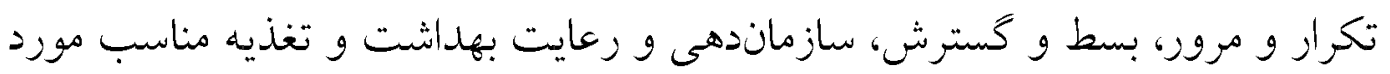
توجه قرار داده است.

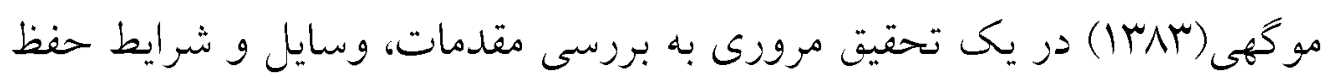

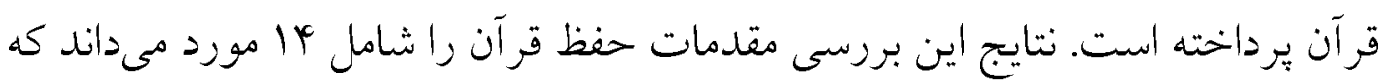

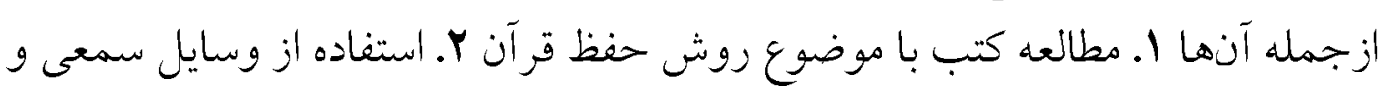


تعيين راهبردهائ ارتقاء بهرهورى آموزش عمومى تمر آن

(روخوانى، حفظ، درك معنا و أنس)

$\mathrm{V}-\mathrm{rg}$

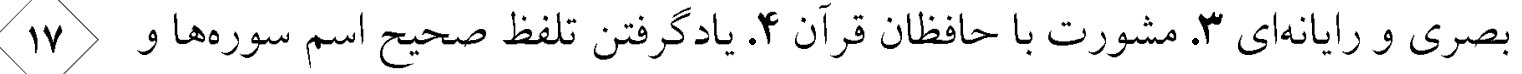

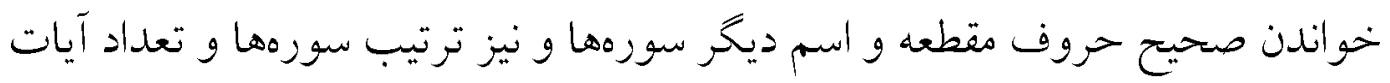

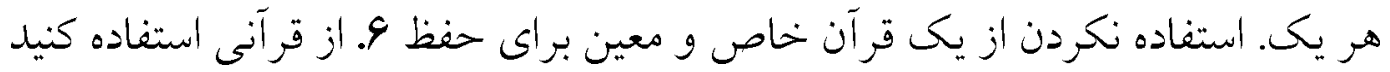

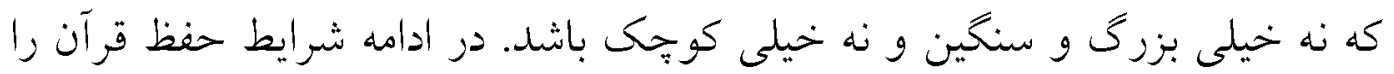

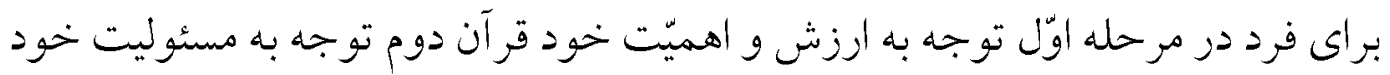

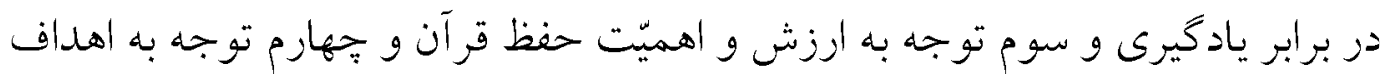
حفظ قر آن مى حاند.

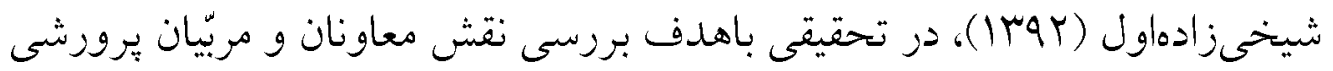

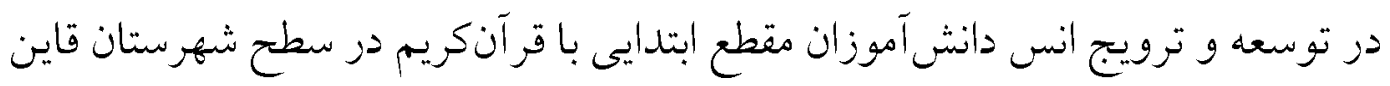

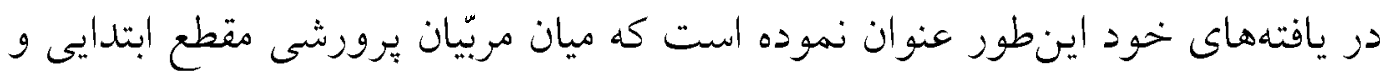

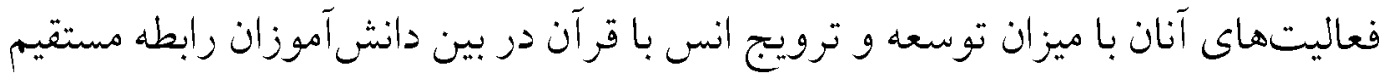

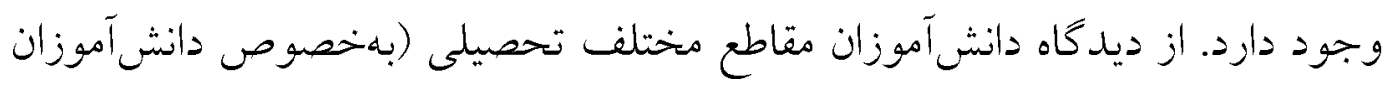

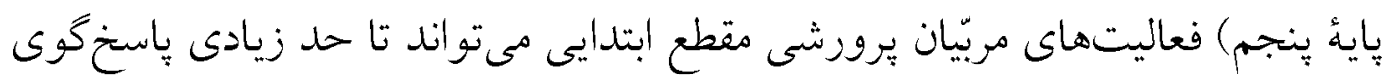

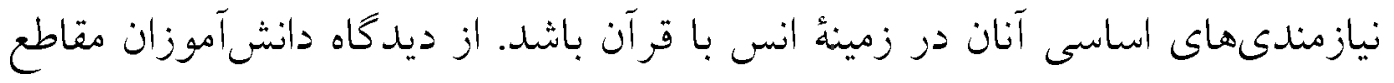

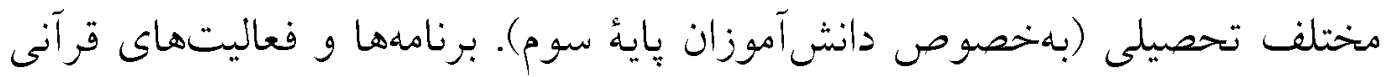

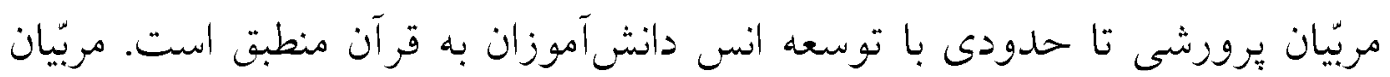

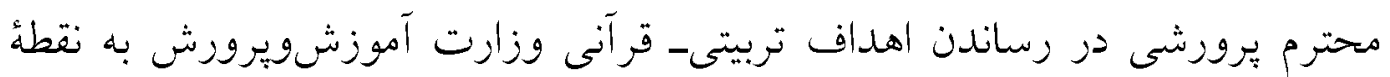
مطلوب هماهنخ و مؤثر عمل نمى كردند.

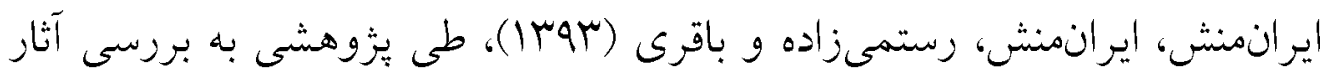

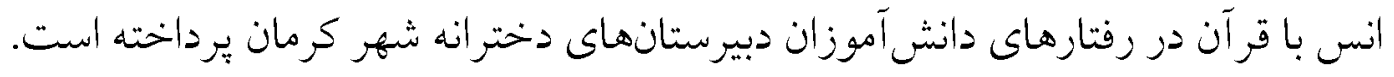

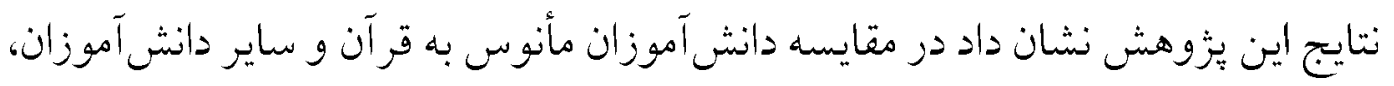

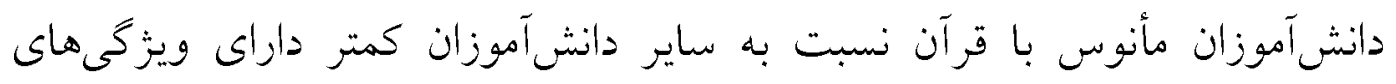

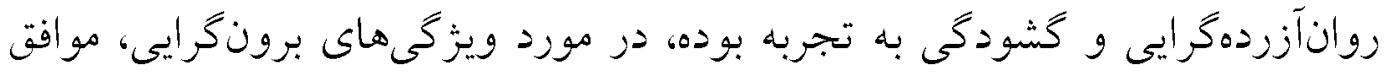

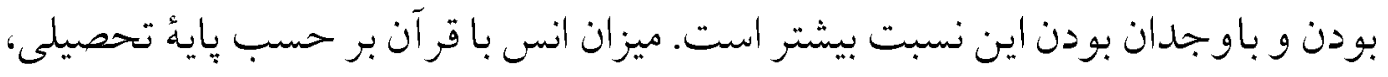

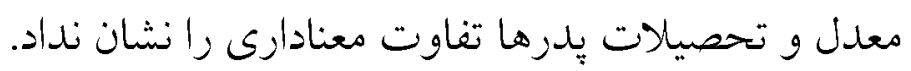

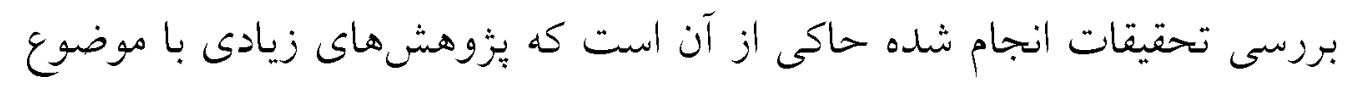


يزوهشها نظام آموزش و يروزش بوده است، كه اين خود حال براهميّت اين موضوع

است. أما از عناوين اين تحقيقات مىتوان دريافت كه بيشتر كارهاى صورت كرفته يا

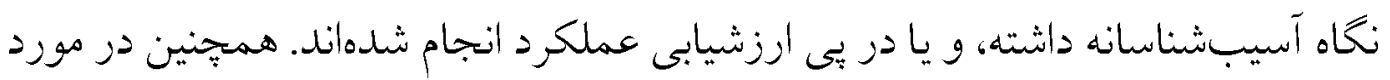

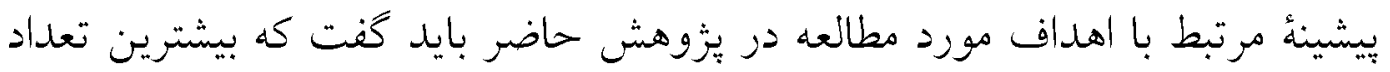
تحقيقات مربوط به هدف روخوانى و حفظ و كمتر به انس و حزك معنا توجه شده است.

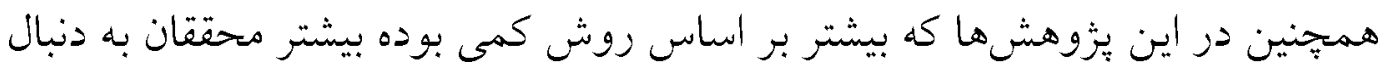

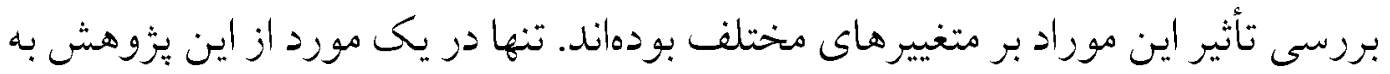

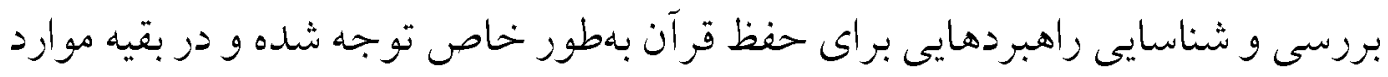

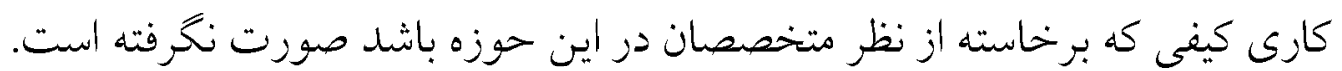

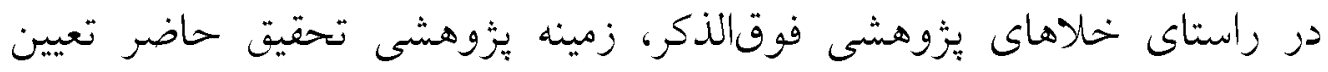

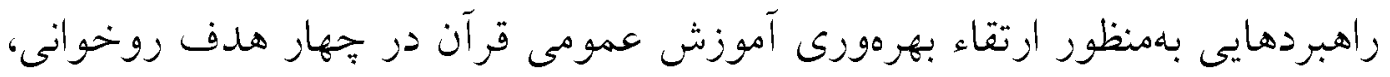

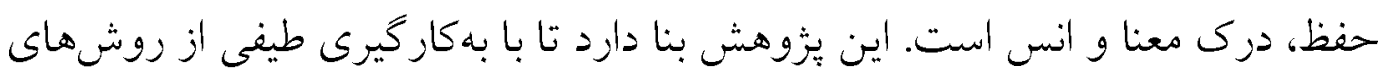

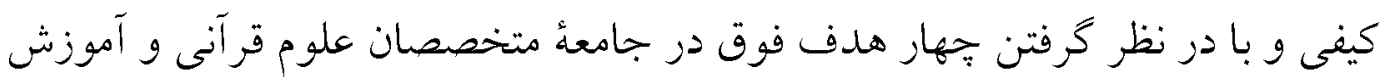

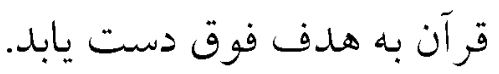

\section{روش بزوهش}

تحقيق حاضر از نظر هدف يثزوهش در ميان تحقيقات كازبردى قراز مى گيرد. همجنين اين تحقيق از نظر زوششناسى، تحقيقى كيفى است. تحقيق حاضر بهدنبال

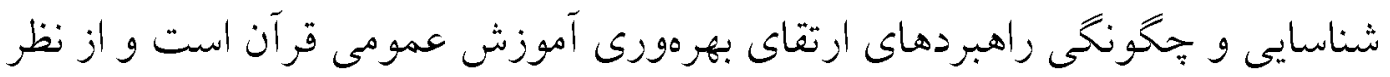
زوششناسى در مجموعه زوش تحقيق كيفى قراز مى كيرد.

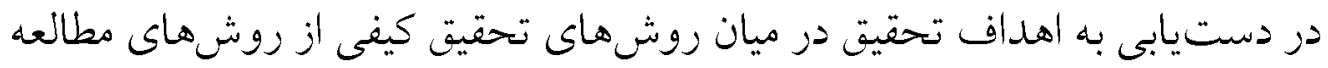
اسنادى، مصاحبه و جلسات بارش فكرى (همانديشى متخصصان) استفاده مى نشود.

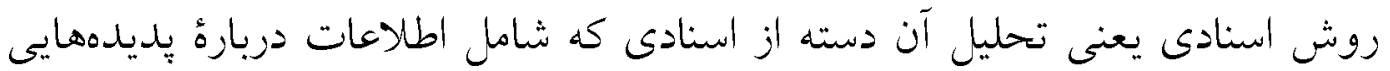

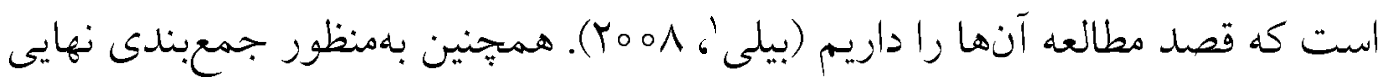

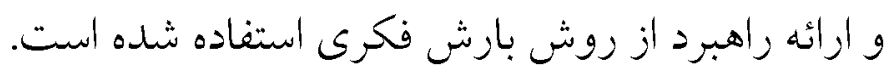

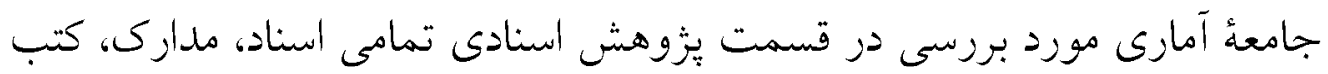


تعيين راهبردهائ ارتقاء بهرهورى آموزش عمومى تمر آن

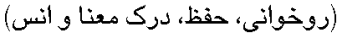

$\mathrm{r}-\mathrm{rq}$

19 و ييشينهاى موجود شامل مقالات، طرحهاى بزوهشى، خبرهاى خبركزارى قرأنى

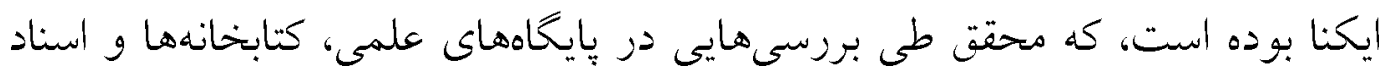

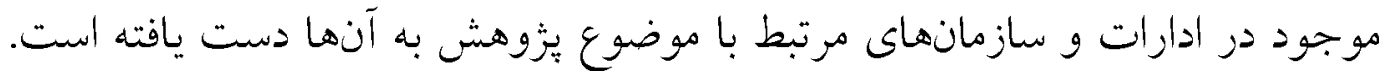

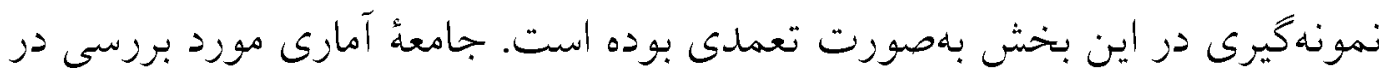

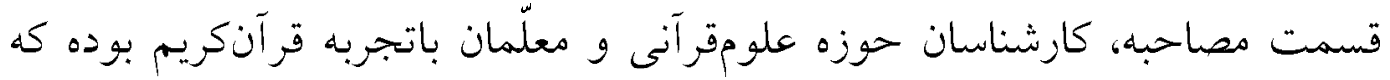

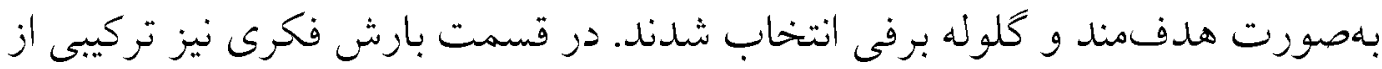

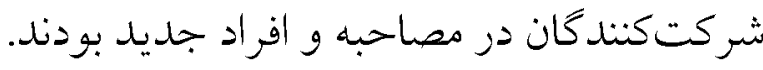

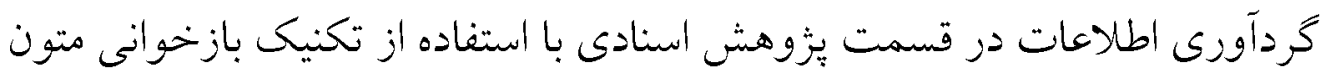

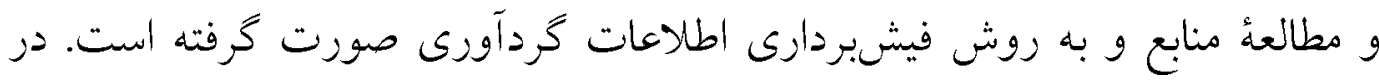

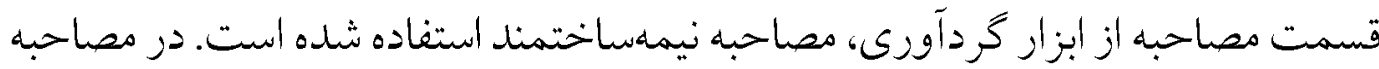
نيمهساختمند، سؤالات از قبل طراحى شده و هدف، كسب اطلاعات عميق از مصاحبه

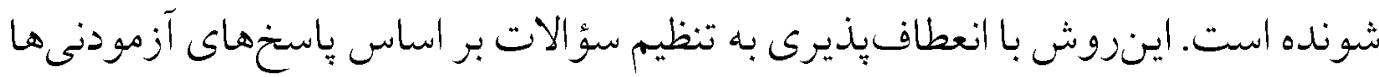

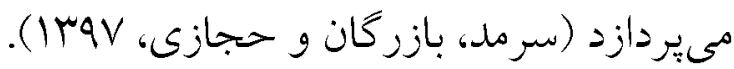
سؤالات مصاحبه، بركرفته از سؤالات تحقيق و بر اساس حو تكنيك STAR و 5W1H

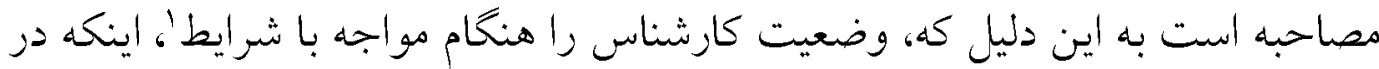

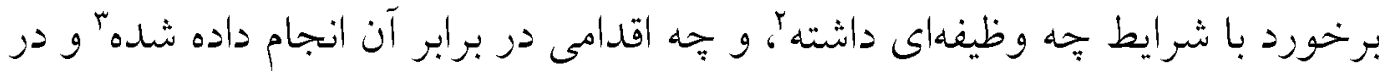

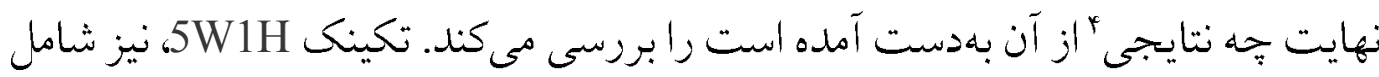

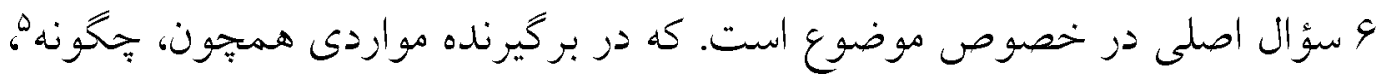

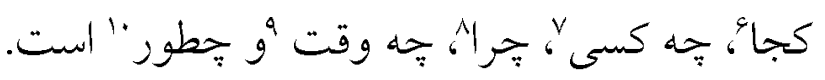

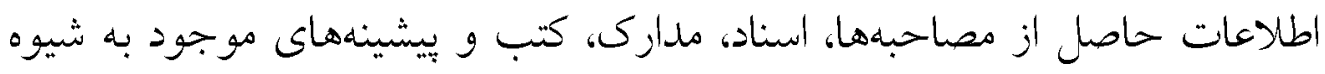

1. situation

2. task

3. action

4. results

5. what

6. where

7. who 
علمى اشتراوس' كدكذارى شدند. كدگذارى نشانگً عملياتى است كه طى آن دادهها

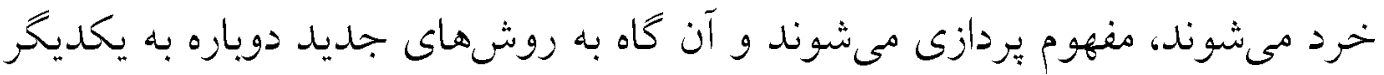

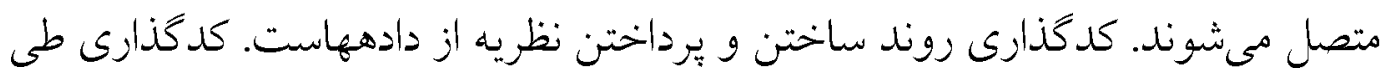

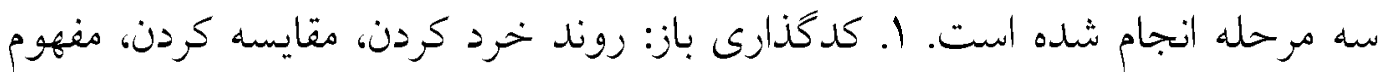

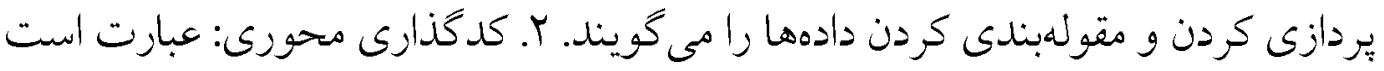

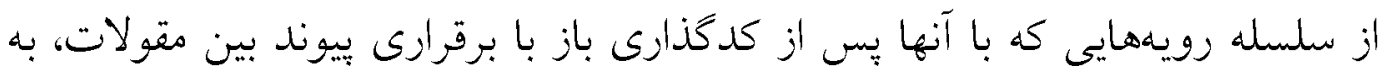

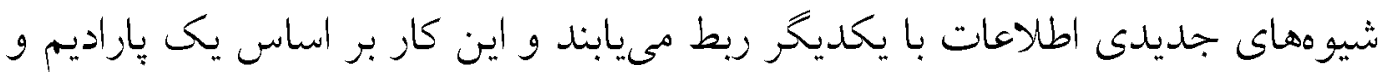

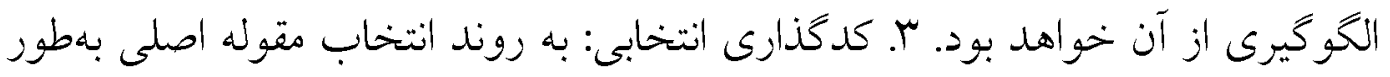

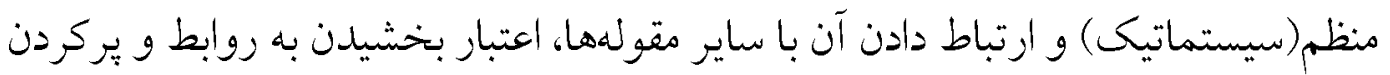

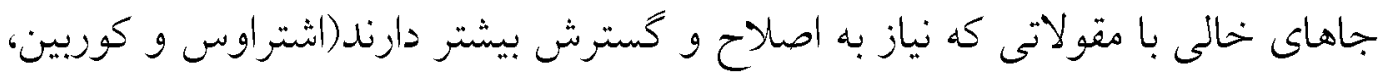

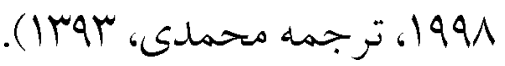

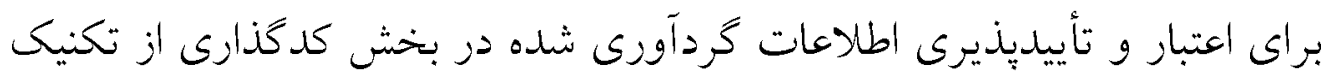

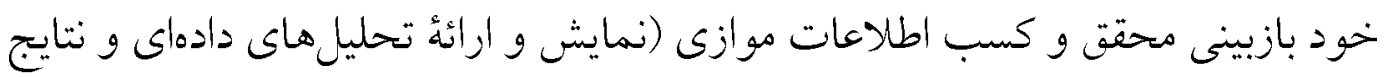

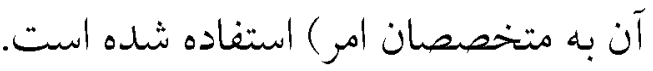

\section{يافتلها}

يس از انجام مصاحبههاى نيمهساختمنل، برزسى اسناد، يزوهش هاى صورت كرفته

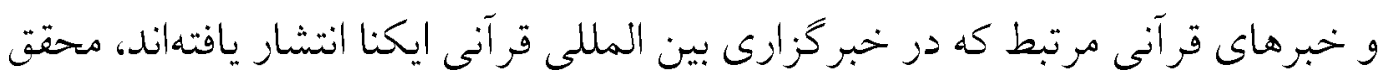

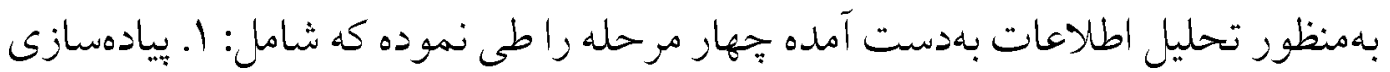

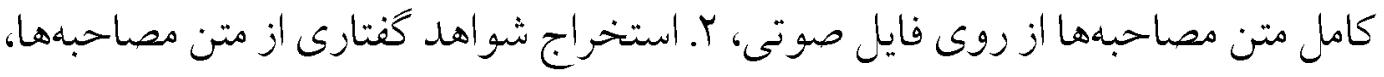

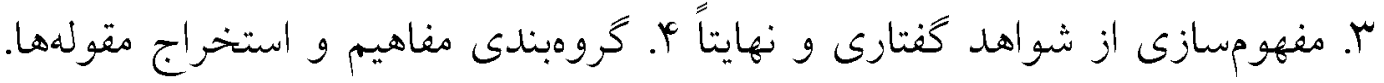
كه بهجز مرحله اوّل كه فقط در مصاحبه متخصصان بوده است بقيه مر احل براى ساير

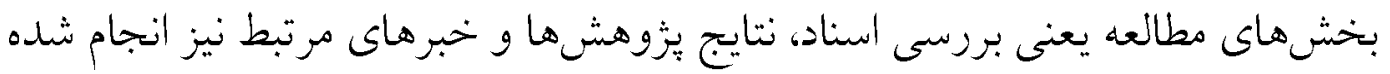

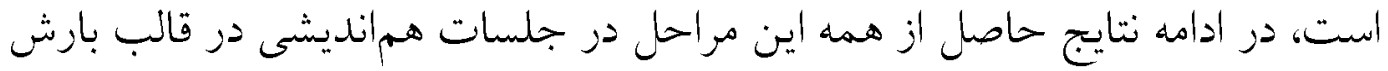

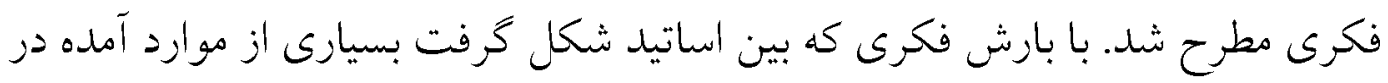

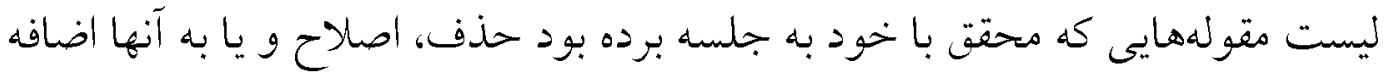


تعيين راهبردهائ ارتقاء بهرهورى آموزش عمومى تمر آن

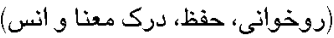

$\mathrm{V}-\mathrm{rq}$

كرديد. تا بلين جا مىتوان كفت كار محقق بإيان يافته و راهبردها بهدت آمده است،

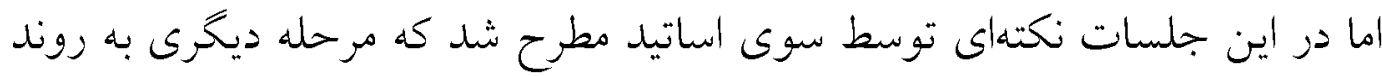

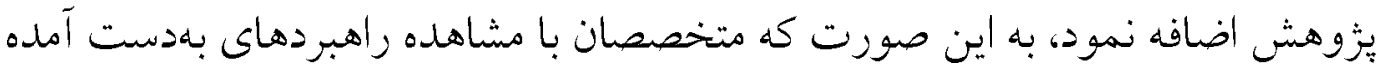

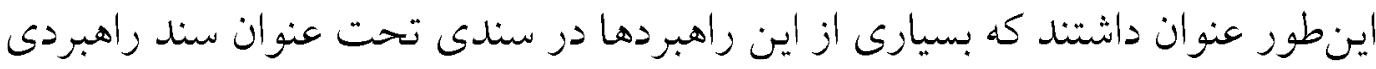

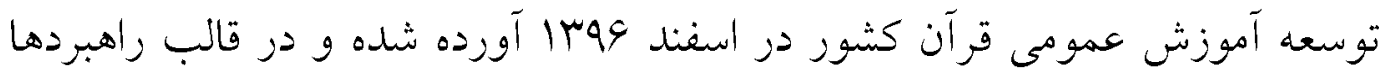

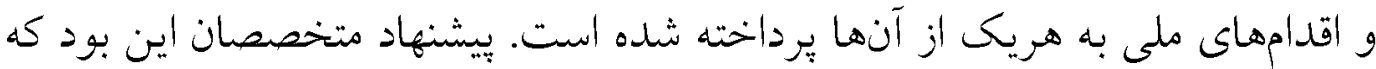

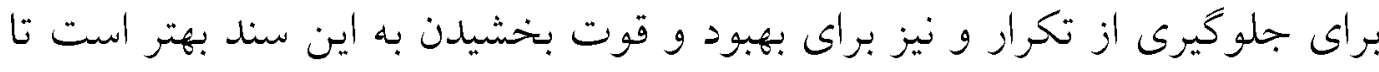

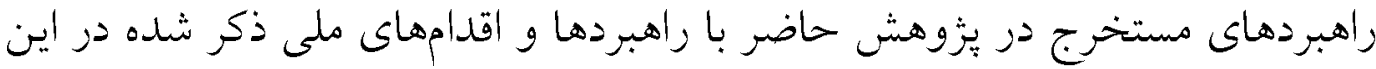

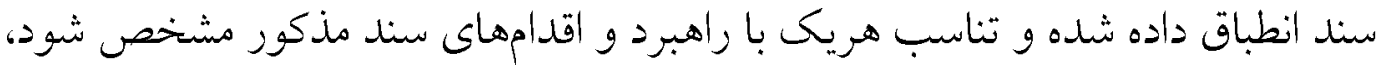

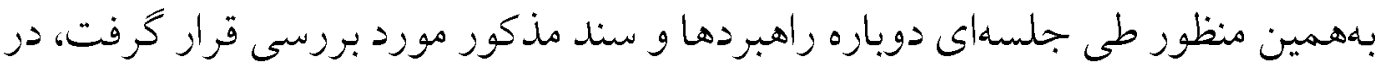

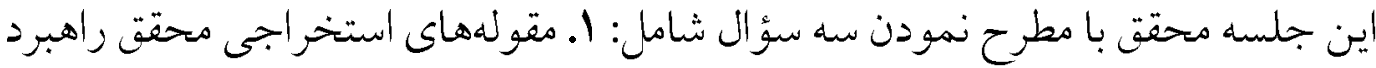

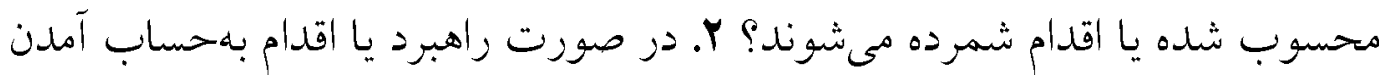

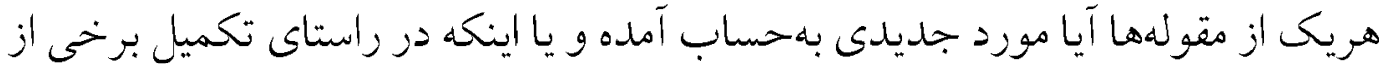

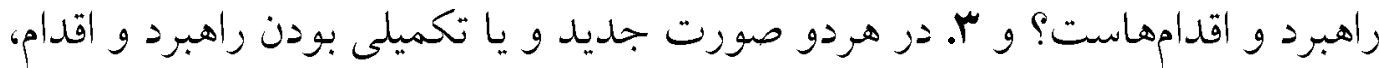

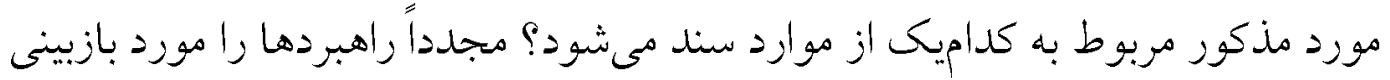

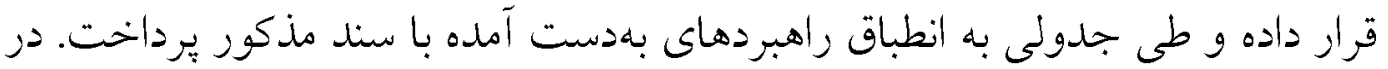

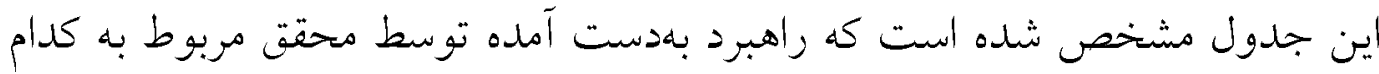

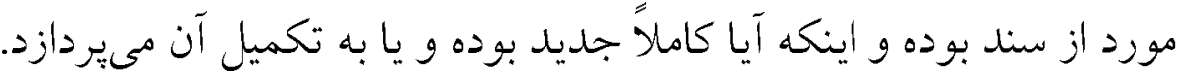

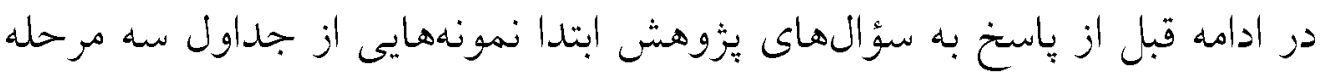

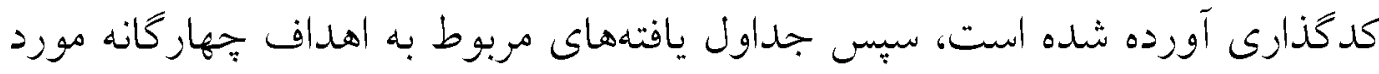

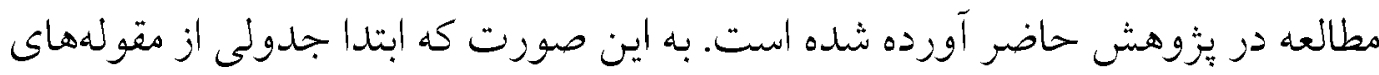

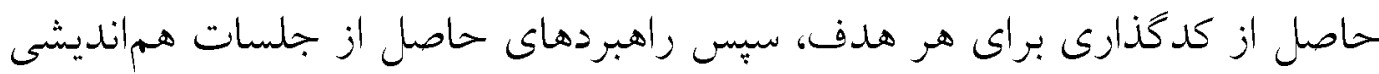

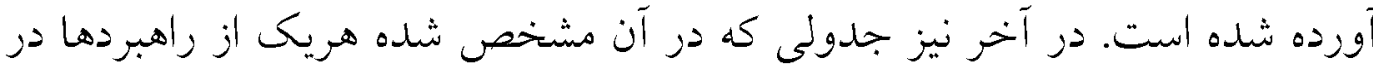

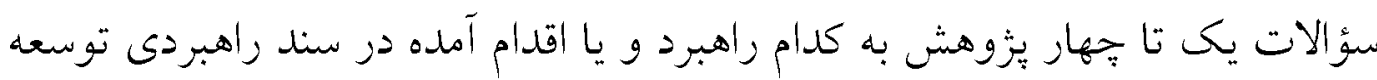

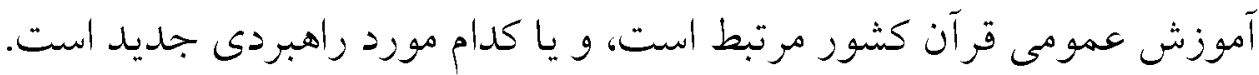

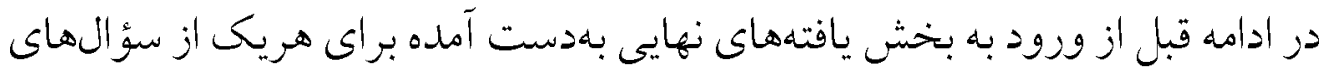

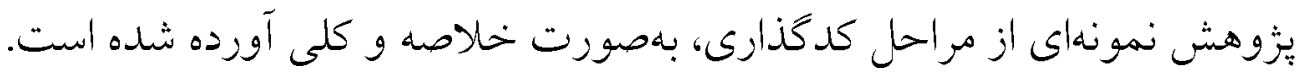


مر حله اول (كد كذارى باز) : شواهد كفتارى همان رخحادها، وقايع و يديلده مو جوت در

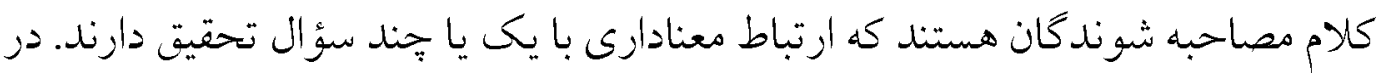

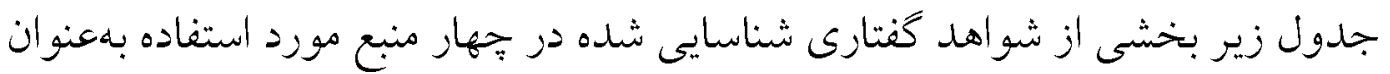

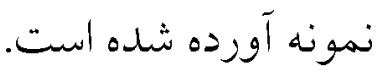

\section{جدول ا. نمونه شواهد كفتارى}

\begin{tabular}{|c|c|c|}
\hline \multicolumn{2}{|l|}{ شواهند كفتارى صورت جلسيات } & ريث \\
\hline \multicolumn{2}{|c|}{ 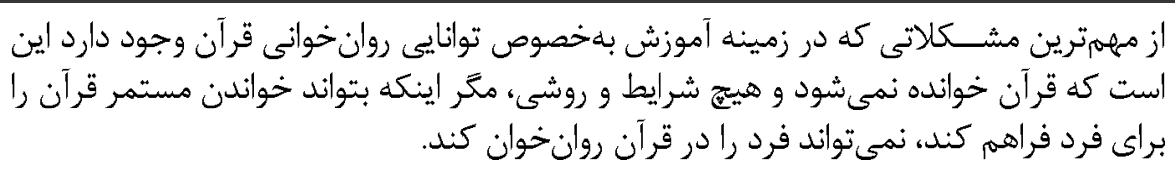 } & Ir-F_a \\
\hline \multicolumn{2}{|c|}{ 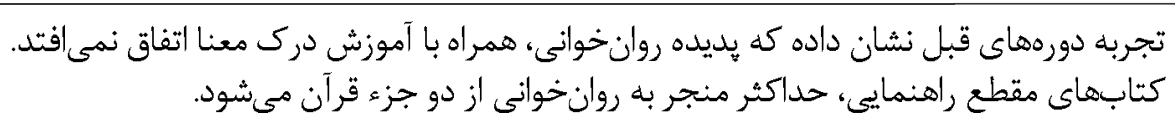 } & $\left|\varphi-\lambda_{-}\right| Y$ \\
\hline \multicolumn{2}{|l|}{ شواهل تَفتارى مصاحبهةا } & ريث \\
\hline \multicolumn{2}{|c|}{ 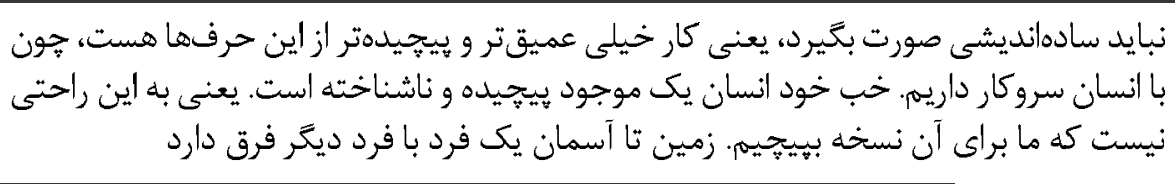 } & $I_{-H} t^{2}$ \\
\hline \multicolumn{2}{|c|}{ 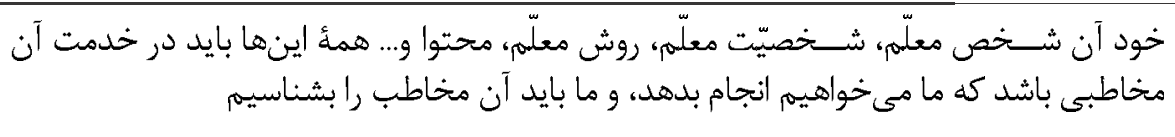 } & $I_{-H}+r$ \\
\hline شو اهد كفتارى خبر هاي قر آني ايكنا & & رديف \\
\hline \multicolumn{2}{|c|}{ 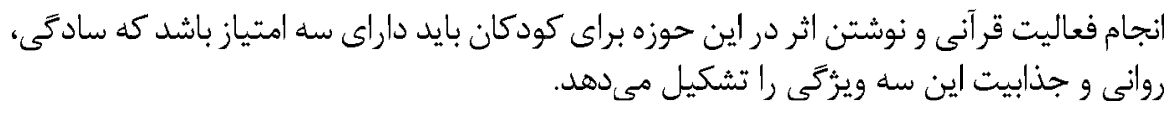 } & 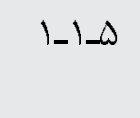 \\
\hline \multicolumn{2}{|c|}{ 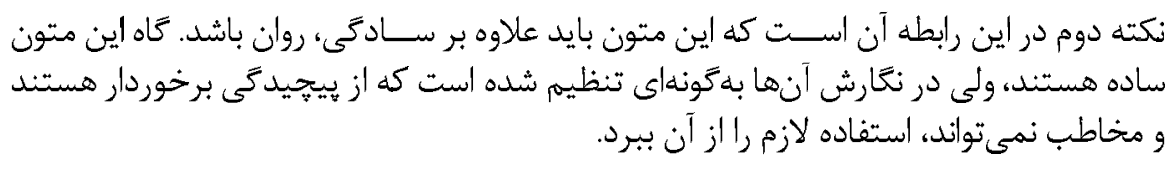 } & $r_{-}$ \\
\hline 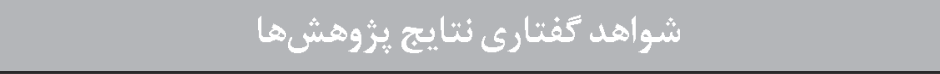 & $2+0$ & رديث \\
\hline 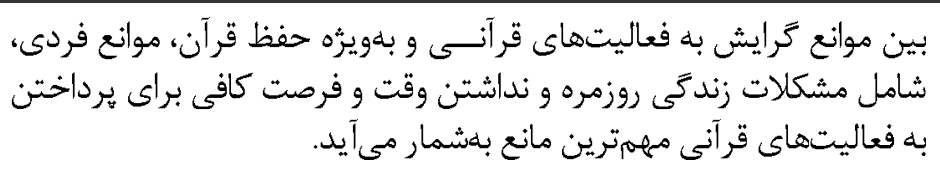 & معصومى اد، & r \\
\hline 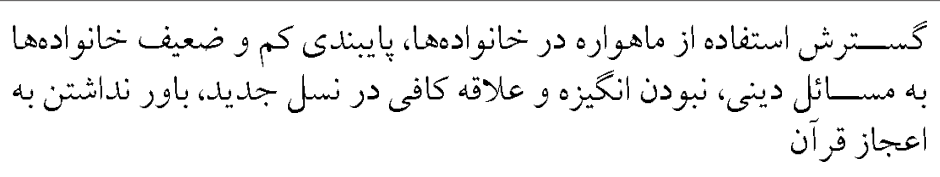 & 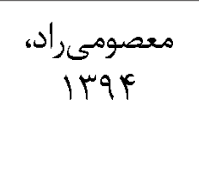 & r \\
\hline
\end{tabular}


تعيين راهبردهايى ارتقاء بهرهورى آموزش عمومى تمر آن (روخوانى، حفظ، درك معنا و أنس)

$\mathrm{V}-\mathrm{rq}$

نر مرحله دوم يعنى كدگذارى محورى، به مفهومسازى هر يكى از شواهد كفتارى يافت شده اقدام شده است. منظور از مفهومسازى اين است كه يك يا جند موزد از شواهد كفتارى استخراج شده در مرحله قبلى را بر مى ماريم، به اجزايى تقسيم ميكنيم و به هر جزء، عنوان و يا برجسبى كه داراى ارثباط مفهومى با آن شواهد هـستند را ارائه مى هيه. نمونهاى از مفهومسازى اوليه حر قالب جدول زير آورده شده است:

\section{جدول r. نمونه مفهومسازى اوليه}

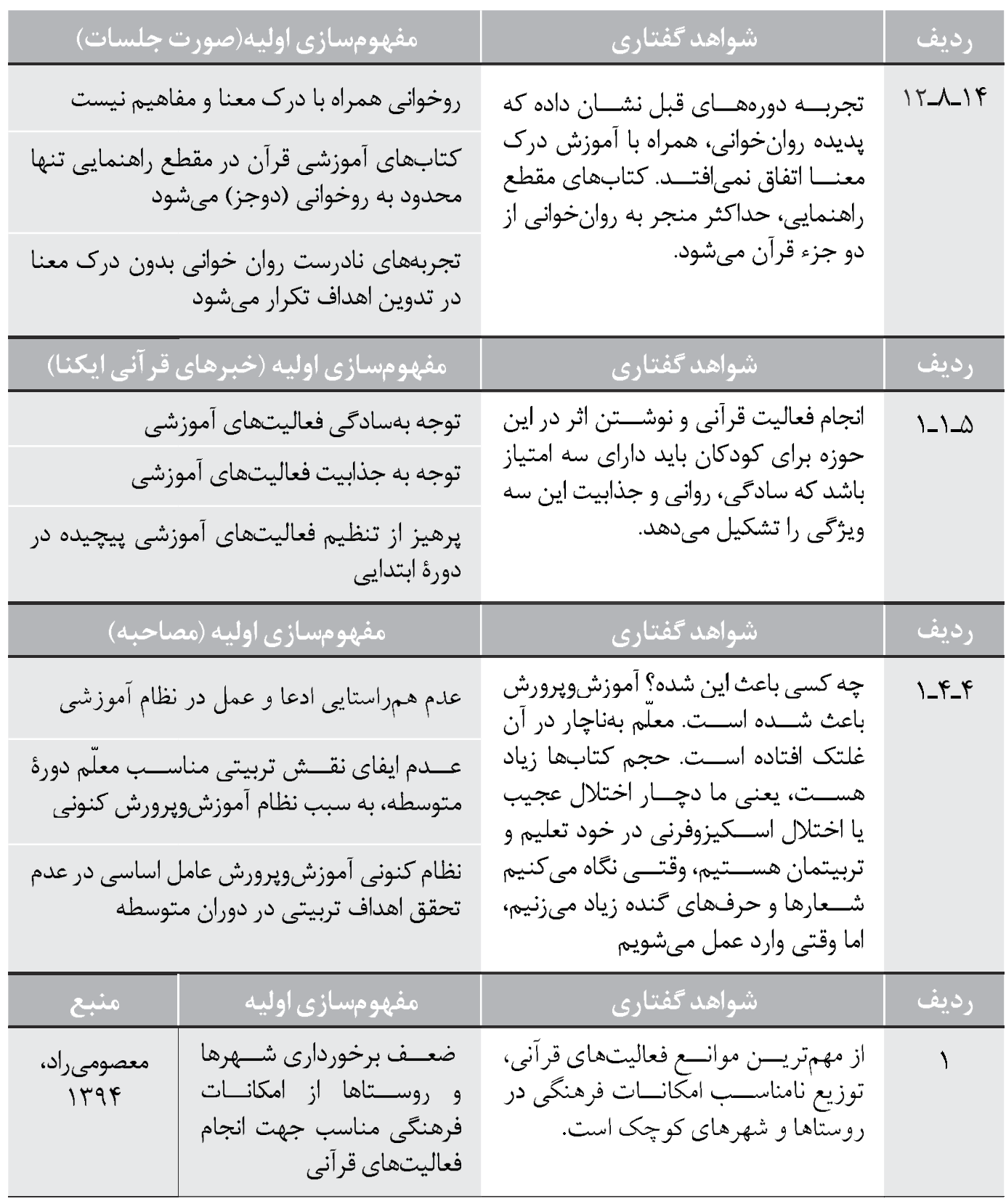


نهايتاً در مر حله سوم يعنى كد كذارى انتخابى، به كروهبندى مفاهيم شناسايى شده بر

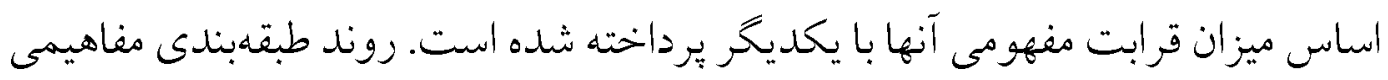

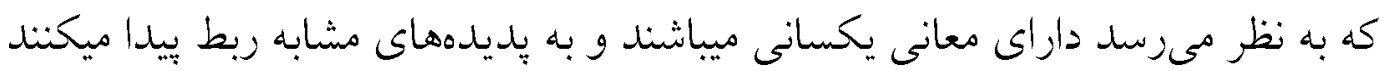

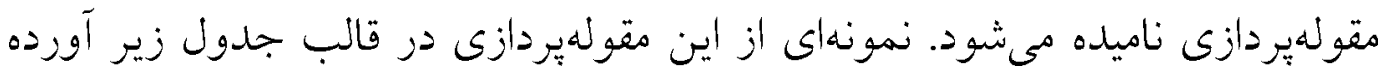

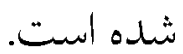

\section{جدول س. نمونه مقوله بندى}

\begin{tabular}{|c|c|}
\hline 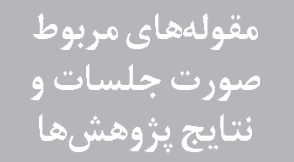 & مفهومشسازى أوليه \\
\hline \multirow{4}{*}{ تعريف نشدن هدف آموزش ترارات } & نامشخص بودن اهداف و انتظارات آموزش قرآن \\
\hline & بالا بودن سطح توقع اهداف از دانشآموز ابتدايى \\
\hline & ناملموس و نامشخص بودن اهداف يادگيرى درس قرآن \\
\hline & ضعف تناسب اهداف آموزشى با توانايى فراگيران \\
\hline 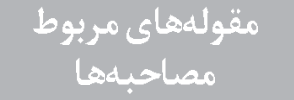 & عفهومسازي اوليه \\
\hline \multirow{4}{*}{ متناسب با مقتضتوات محتات } & لزوم انتخاب محتواى كاربردى براى مخاطب با نظر به مقتضيات مكان \\
\hline & لزوم انتخاب محتواى كاربردى براى مخاطب با نظر به مقتضيات زمان \\
\hline & لزوم تناسب محتوا با ويزّكى هاى جغر افيايى منطقه \\
\hline & يرهيز از ارائه محتواى يكسان براى تمامى استانهاى كشور \\
\hline 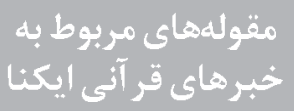 & مفهومسازي اوليه \\
\hline \multirow{3}{*}{ متخصركين از تخصص توليد } & الكَوَيرى از سبك آقاى قرائتى در آموزش قرآن \\
\hline & بهرهگيرى از آثار نويسندكان آكاه براى توليد محتوا جهت ردهماى سنى مختلف \\
\hline & بهرهگيرى از آثار اثربخش در آموزش قرآن \\
\hline
\end{tabular}


تعيين راهبردهايى ارتقاء بهرهورى آموزش عمومى تمر آن

(روخوانى، حفظ، درك معنا و انس) ترني)

$v-r q$

حر نتيجه انجام مراحلا فوق بر روى مصاحبههاى كد كذارى شده، تعلاد مل مقوله بر اساس همه سؤالات تحقيت استخراج شه. در ادامه، هريك از اين مقولات به تفكيك اله سؤ الات تحقيت آورده شلده است.

\section{هدف اوّل و دوم: خواندن و درك معناى آيات}

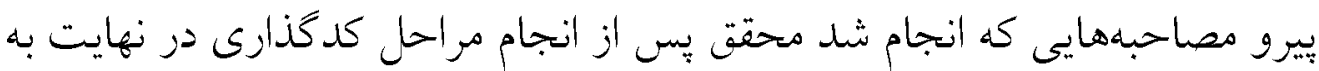

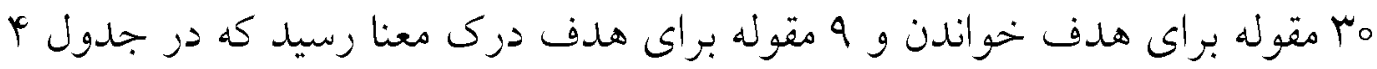
آورده شده است. جدول F. مقولههاى حاصل از كدكذارى مرتبط با توانايى خواندن و درك معناى آيات قر آنكريم

\begin{tabular}{|c|c|}
\hline \multicolumn{2}{|c|}{ توانيى خواندن قر آنكريم } \\
\hline غور و تفحص در قرآن & ارائه تعريف صحيح از توانايى خواندن قرآن \\
\hline توجه نكردن صرف به ظواهر دين & توجه به كيفيت قرائت قرآن \\
\hline تشويق عموم به فراگيرى قرآن & تقويت درى صحيح از شيوههاى آموزش قرآن \\
\hline ت تأكيد بر فهم قرآن & تقويت تأثيريذيرى از قرآن \\
\hline تأكيد بر مداومت در آموزش قرآن & برطرف ساختن ضعف در درى قر آن \\
\hline توجه هرجه بيشتر به انس با قرآن & استمرار در قرائت قرآن (مداومت در خواندن قرآن) \\
\hline متمايز ساختن مرز روخوانى و درى مورى مفاهيم & تقويت مهارت در روخوانى و روانخوانى درو ابتدايى \\
\hline توأمان نمودن روخوانى بافهمى و درك معنا & اجراى صحيح برنامههاى ابلاغ شده \\
\hline اصلاح روش آموزش روخوانى در دورة ابتدايى & اصلاح روشهاى آموزش \\
\hline توأمان نمودن روخوانى با انس بد قرآن & توجه به آموزش عمومى قرآن \\
\hline تدوين برنامهاى مدون و منظظم براى ترت ترتيل & اصلاح روشهاى خواندن \\
\hline مستمر نمودن فرايند و شيوههاى يادكيرى & توجه به تفاوتهاى فردى در آموزش \\
\hline ارائه تعريف مناسب از قرائت & همراه ساختن روخوانى با روانخوانى در آموزش قرآن \\
\hline تأكيد بر آموزش روخوانى قرآن در دورة ابتدايى & تأثير مثبت رسم|الخط فارسى در ياد گيرى قرآنكريمم \\
\hline آموزش مبتنى بر روشهاى شنيدارى & استفاده از روشهاى نافع در آموزش قرآن \\
\hline
\end{tabular}




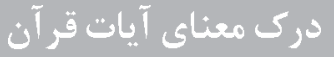

\begin{tabular}{|c|c|}
\hline آموزش قرآن بـ شيوذ تقطيع & با اهداف آموزش خوب كتب درسى قرى آن \\
\hline تأكيد بر فن بيان در آموزش قرآن & آموزش فرازهاى قرآنى با شيوء داستان َّويى \\
\hline بهبود نحوء انتقال آموزههاى قرآنى & بالا بردن فهمم كليات قر آن \\
\hline بهرهگيرى از فن بيان مناسب & تمركز بر آموزش فعال \\
\hline & تكيه نكردن صرف بر وازمهاى قرآنى و ترجمه آنها \\
\hline
\end{tabular}

راهبردهاى حاصل از فرايند كدكذارى دز جدول بالا در جلسه همانديشى مطرح

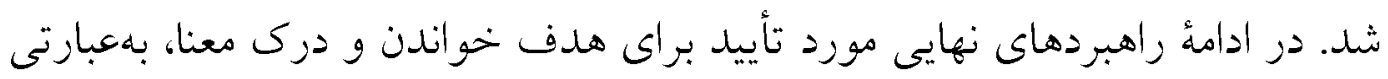

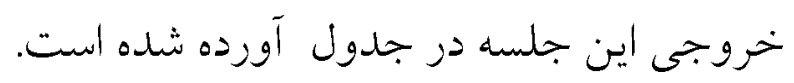

جدول ه. راهبر دهاى اوليه حاصل از جلسه همانديشى مرتبط با توانايى خواندن

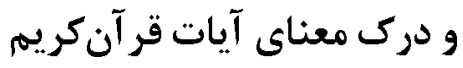

\begin{tabular}{|c|c|}
\hline راهبر ثهاي & 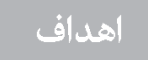 \\
\hline تعريف و تبيين قرائت قرآن & \multirow{6}{*}{ توراندانيى } \\
\hline تأكيد بر مداومت در قرائت قرآن جهت تحقق انس با قرآن & \\
\hline بازنتَرى و اصلاح روشهاى آموزش قرائت قرآن & \\
\hline توأمان نمودن روخوانى با انس به قرآن & \\
\hline كَسترش و تعميق فرهنَ قر آنخوانى در سطح آموزش عمومى & \\
\hline تمركز بيشتر در آموزش قرائت قرآن بر روشهاى شنيدارى & \\
\hline طراحى نظام كار آمد آموزش عمومى قرآن بر اساس درك صحيح از مفاهيم قرآن & \multirow{4}{*}{ ديات درى } \\
\hline تقويت تأثيريذيرى و درى قرآن & \\
\hline انطباق كتب درسى با اهداف آموزش عمومى قرآن & \\
\hline تكيد نكردن صرف بر وازٔههاى قرآنى و استفاده از ترجمههاى تفسيرى علاوه بر ترجمه آيات & \\
\hline
\end{tabular}




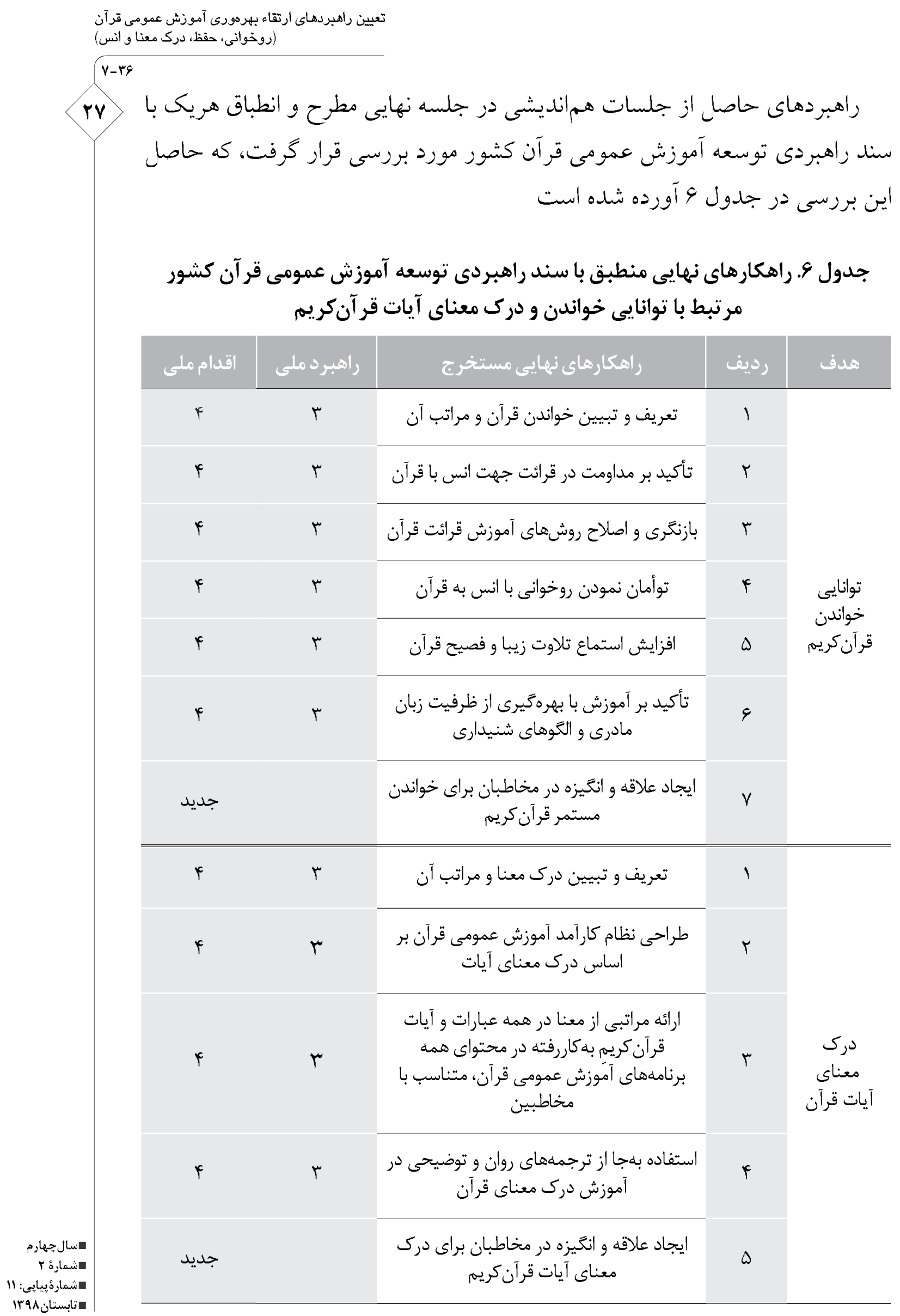




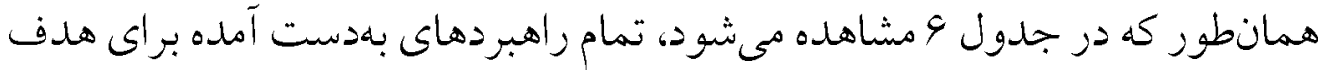

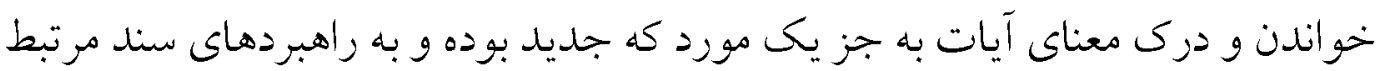

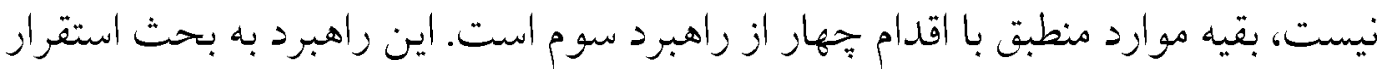

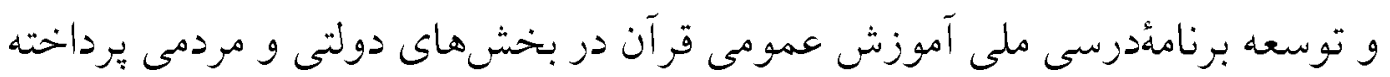

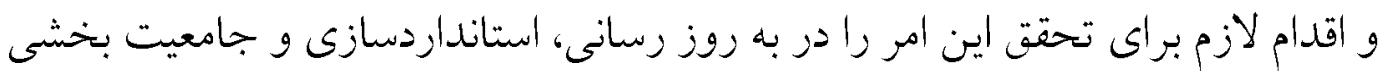

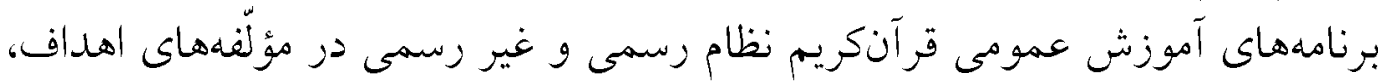

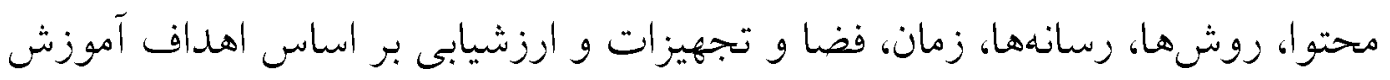

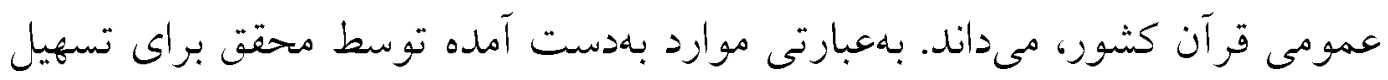

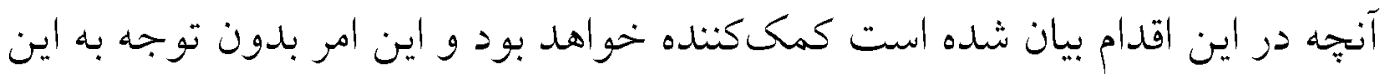
موارد ميسر نخو اهد شد.

\section{• هدف سوم: حفظ قرآن كريم}

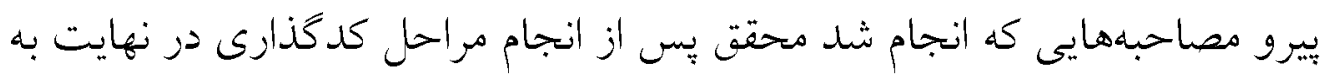

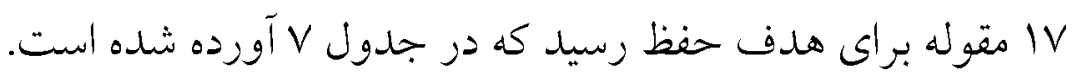
جدول V. مقولههاى حاصل از كدكذارى مر تبط با حفظ قر آنكريم

\begin{tabular}{|c|c|}
\hline \multicolumn{2}{|c|}{ 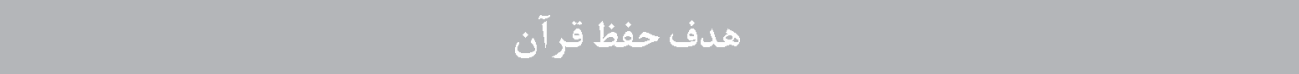 } \\
\hline تلاش براى رسيدن به حفظ تخصصى قرآن & تأكيد بر حفظ نسبى آيات نامدار \\
\hline توجه به شيوههاى تسهيل حفظ قرآن & تمركز بر حفظ نسبى آيات نامدار \\
\hline ارائه تعريف روشن از حفظ قرآن & طراحى نظام حفظ قرآن در سازمان آموزش و يرورش \\
\hline يرهيز از نخبهيرورى در آموزش عمومى & 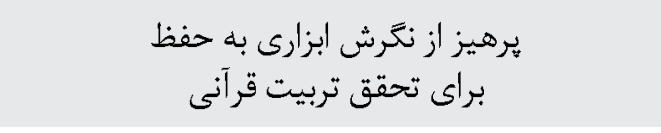 \\
\hline به كار كرفتن قوه استماع در يادگيرى قرآن & غافل نشدن از حفظ موضوعى قرآن \\
\hline در جهت فيرى روشهال جردن قوه استماع & توجه به معانى و مفاهيم قرآن \\
\hline 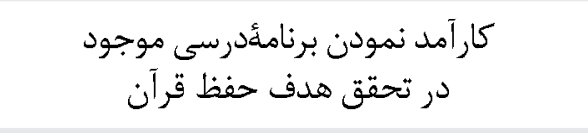 & تقويت روحيه ايمان و باور به قرآن \\
\hline \multirow[t]{2}{*}{ عدم تمركز بر حفظ تخصصى در برنامد درسى } & تمركز بر يادگيرى معنادار در حفظ آيات \\
\hline & آغاز آموزش حفظ قرآن از سن مناسب \\
\hline
\end{tabular}


تعيين راهبردهائ ارتقاء بهرهورى آموزش عمومى تمر آن (روخوانى، حفظ، درك معنا و أنس)

$\mathrm{V}-\mathrm{rq}$

ra راهبردهاى حاصل از فرايند كدكذازى دز جدول بالا در جلسه همانديشى مطرح

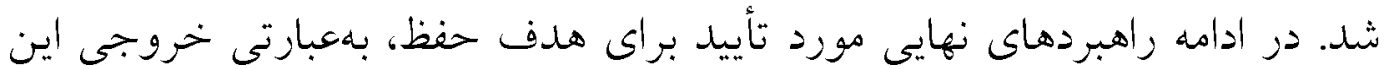
جلسه ير جاول ه آورده شده است.

جدول ^. راهبر دهاى اوليه حاصل از جلسه هم/انديشى مرتبط با حفظ قر آنكريم

Los, 0 i)

i|tiol

تأكيد و تمركز بر حفظ نسبى آيات نامدار در آموزش عمومى قرآن طراحى نظام حفظ قرآن در سازمان آموزش و برورش هرهيز از نكرش ابزارى به حفظ براى تحقق تربيت قرآنى تمركز بر يادگيرى معنادار در حفظ آيات قرآن حفظ تقويت و ترويج فرهنى حفظ قرآن تعامل اثربخش و فعال دانشآموزان با قرآن و ارتقاء اين تعامل بكوسيله حفظ جهت تحقق انس با قرآن

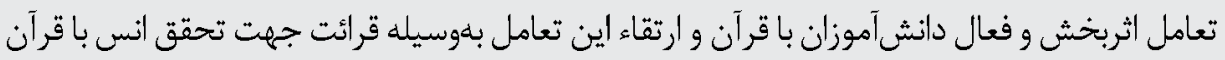

راهبردهاى حاصل از جلسات هـمانديشى دز جلسه نهايى مطرح و انطباق هريك با سند راهبردى توسعه آموزش عمومى قرآن كثوز مورد بررسى قرار كرفت، كه حاصل

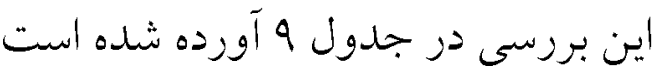

جدول 9. راهكارهاى نهايى منطبق با سند راهبردى توسعه آموزش عمومى قر آن كشور مر تبط با حفظ قر آنكريم

\begin{tabular}{|c|c|c|c|}
\hline ملى إن & إنلى اهبرد & راهكار هاي نهائي مستخرج & رديث \\
\hline y & r & تعريف و تبيين حفظ قرآن و مراتب آن & 1 \\
\hline r & 1 & تأكيد بر حفظ آيات نامدار، كاربردى و حاوى معارف اساسى قرآنكريمم & r \\
\hline r & 1 & طراحى و استقرار نظام حفظ قرآن در خارجوب اهداف آموزش عمومى قرآن & $r$ \\
\hline r & 1 & بهرهكيرى از حفظ بهمنظور تحقق تربيت قرآنى و يرهيز از نكرش ابزارى به آن & f \\
\hline r & 1 & حركت بلسوى انكَيزشهاى متعالى درونى در حفظ قرآنكريم براى تحقق تربيتدينى & \\
\hline r & 1 & يرهيز از ترويج حفظ بدون درك معناى آيات & 4 \\
\hline$\wedge$ & & تقويت و ترويج فرهنگ حفظ قرآن در خانوادهها و محيطهاى آموزشى & V \\
\hline جديد & & ايجاد علاقه و انكيزه در هخاطبان براى حفظ قرآنكريم & $\wedge$ \\
\hline
\end{tabular}




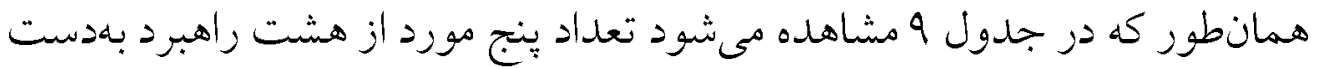

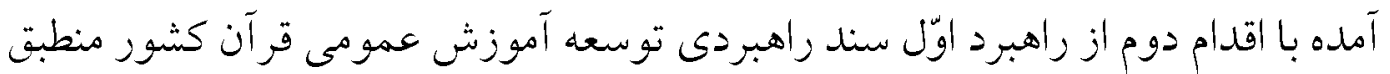

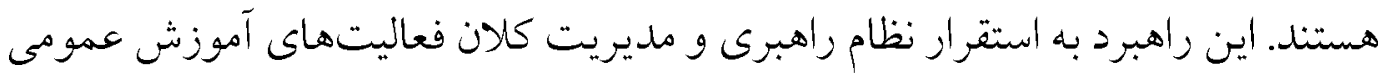

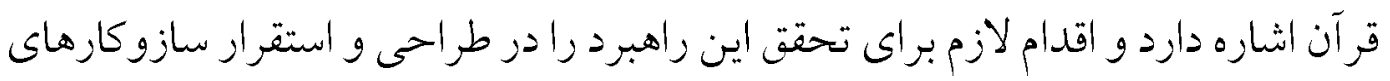

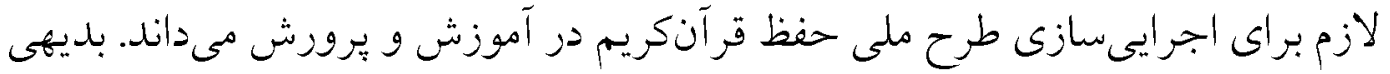

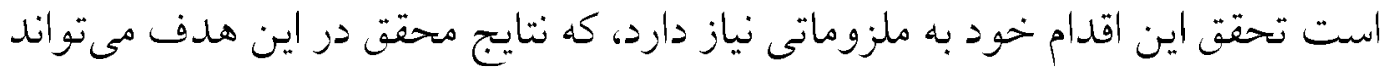

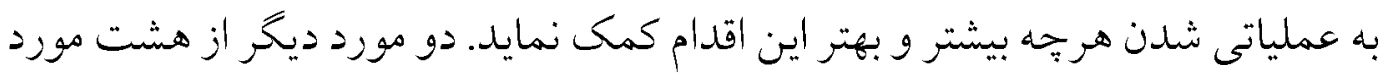

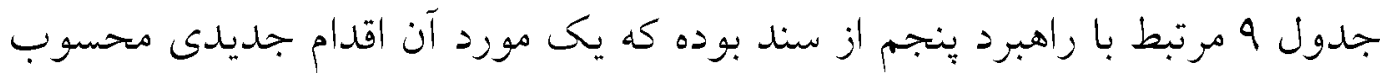

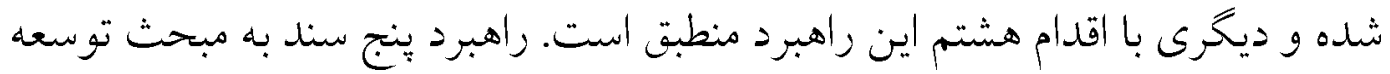

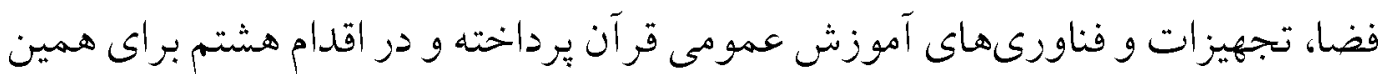

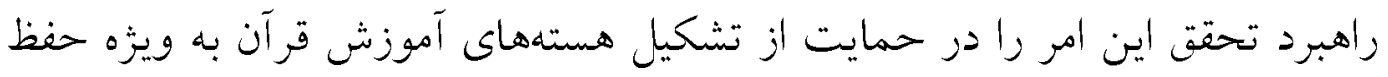

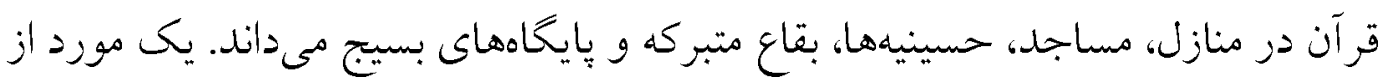

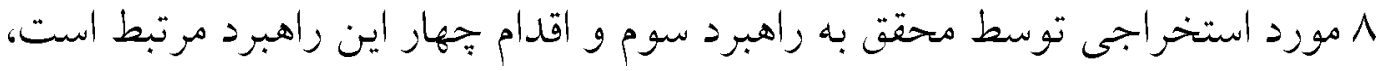

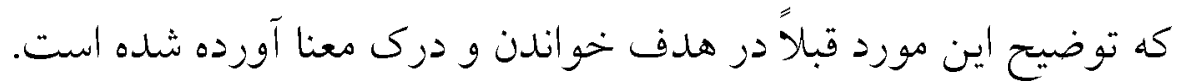

\section{• هدف جهمارم: انس با قرآن}

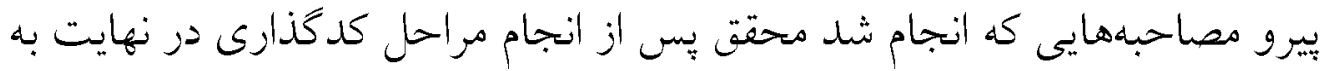

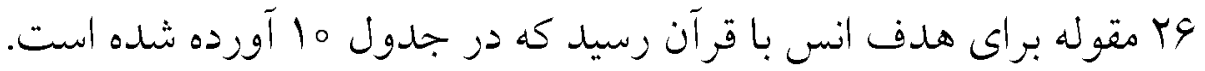

جدول 10. مقولههاى حاصل از كدكذارى مرتبط با انس با قر آنكريم

\begin{tabular}{|c|c|c|}
\hline \multicolumn{2}{|c|}{ أس با قرآنكريم } & קدنف \\
\hline ايجاد تنوع در شيوههاى اتتقال آموزهماى قرآنى & فقر فرهنتى عامل مؤثر در عدم تحقق انس با قرآن & 1 \\
\hline درك صحيح از مفهوم انس با قرآن & 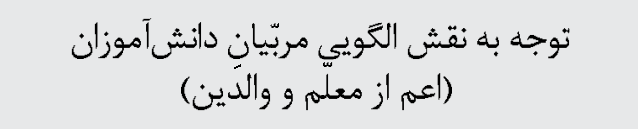 & r \\
\hline يرهيز از تأكيد صرف و وافر بر روخوانى و & بلهكاركيرى شيوهماى آموزش مؤثر و متنوع در & $r$ \\
\hline عجين شدن با قرآن & 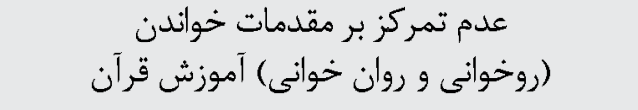 & $F$ \\
\hline
\end{tabular}




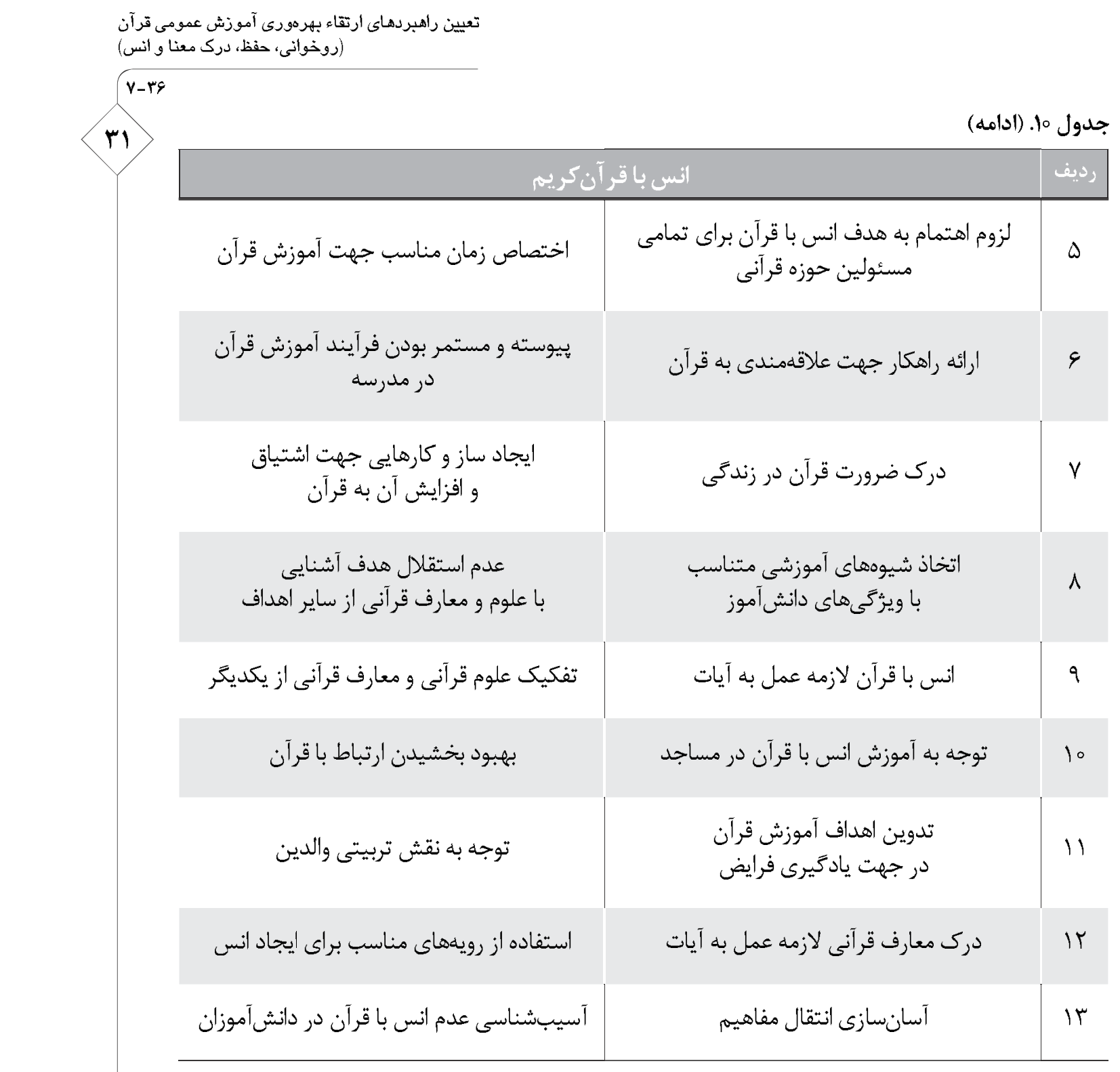

راهبردهاى حاصل از فرايند كدكذارى در جدول بالا در جلسه همانديشى مطرح

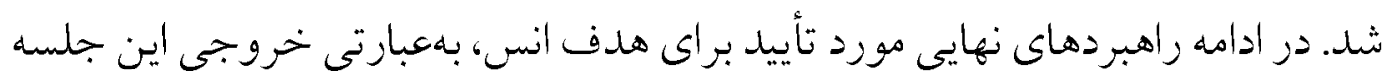

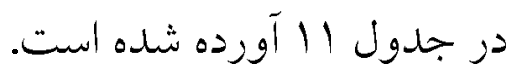

جدول II. راهبر دهاى اوليه حاصل از جلسه همانديشى مر تبط با انس با قر آنكريم

\begin{tabular}{|c|c|}
\hline اراهبر وها & اهداف \\
\hline توجه به نقش الكَويى مربيّان دانشىآموزان (اعمه از معلّم و والدين) & \\
\hline تعريف و تبيين درك صحيح از مفهوم انس با قرآن & 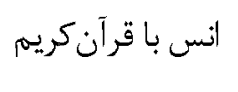 \\
\hline نهادينهسازى احساس ضرورت يادَّيرى قرآن در زندىى & \\
\hline
\end{tabular}


راهبردهاى حاصل از جلسات هم انديشى در جلسه نهايى مطرح و انطباق هريك با

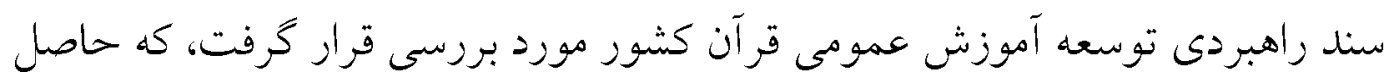

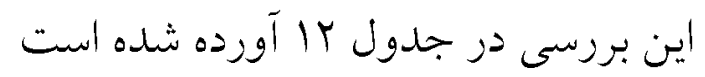

جدول זا. راهكارهاى نهايى منطبق با سند راهبردى توسعه آموزش عمومى قر آن كشور مرتبط با انس با قر آنكريم نوسئ

\begin{tabular}{|c|c|c|c|}
\hline ملى اقلم & مالهبيرد & راهكار هاي نهايي مستخرج & ردفض \\
\hline f & $r$ & تعريف و تبيين مفهوم انس با قرآنكريمم & 1 \\
\hline جديد & 1 & ايجاد علاقه و انكَيزه در مخاطبان براى انس با قرآنكريمم & $r$ \\
\hline r & 1 & كَسترش و تعميق فرهنَ قر آن خوانى در سطح آموزش عمومى & r \\
\hline$\wedge$ & $\Delta$ & تبيين و ترويج نقش ويرٔه حفظ در ايجاد و تقويت انس با قرآنكريمم & r \\
\hline
\end{tabular}

همانطور كه در جدول r| إمشاهده مىشوح جهار مورد راهبرد براى هدف انس

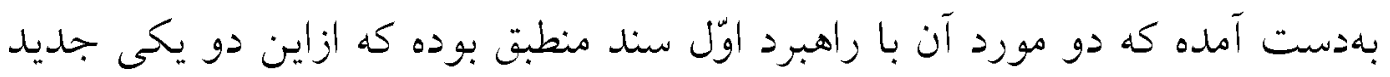

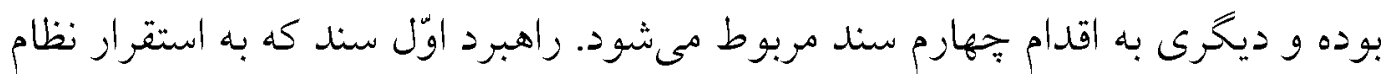

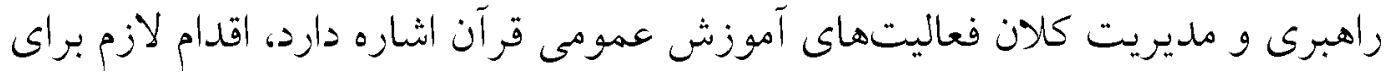

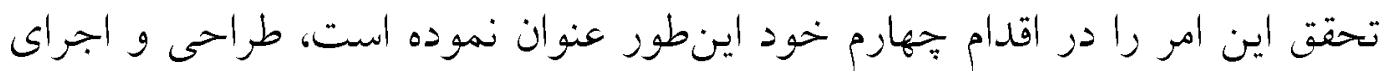

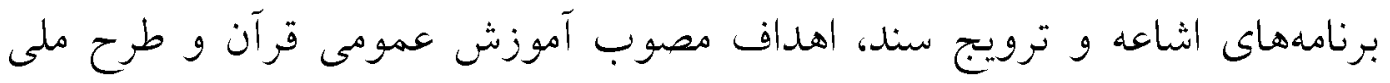

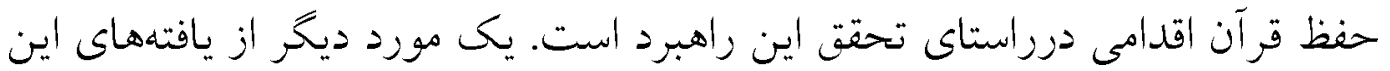

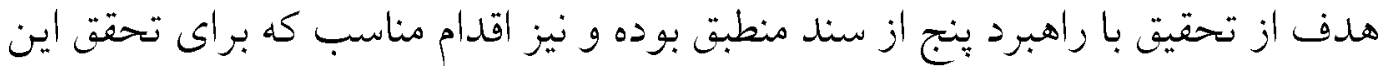

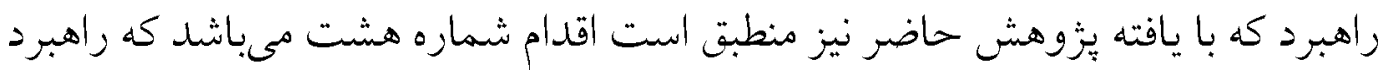

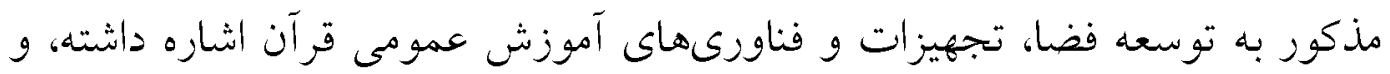

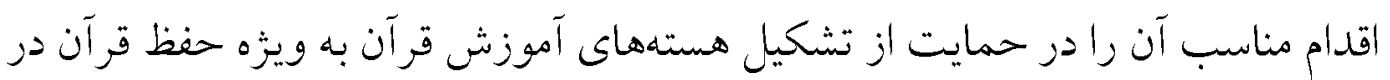

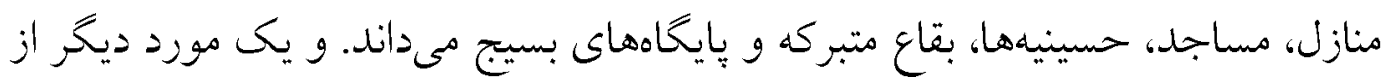

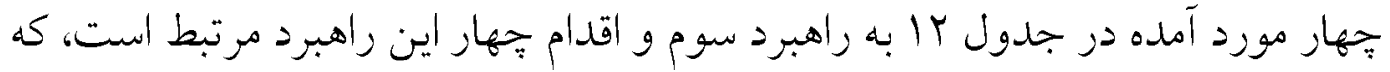

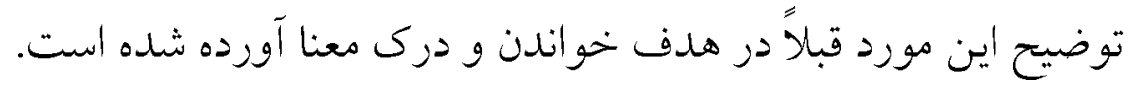


تعيين راهبردهاى أرتقاء بهرهودى آموزش عمومى قرآن

(روخوانى، حفظ، درك معناو أنس)

\section{نتيجلهَيرى}

هدف از يزوهش تعيين راهبردهاى ارتقاء بهروورى آموزش عمومى قرآن است. نتايج بررسىهاى بهعمل آمله، حز اين يثوهش نشان مى بهد كه راهبردهاى زيادى وجود دارد كه مىتوان به كمك آنها روند آموزش قرآن به ويزه در جهار هدف خو أندن، لركى معنا، حفظ و انس بهبود بخشيد. مىتوان كفت راهبرغهايى كه اين تحقيت به آنها زسيده است به نوعى به تمام ابعاد اثركذار در امر آموزش قرآن اشاره داشتهاند. حر أين راهبردها به نقش مربى، والدين، محتوا، برنامهُ درسى، نظام آموزشى، سيستم ارزشيابى، انخيزش دانش آموزان، تفاوتهاى فردى، برنامهزيزى آموزشى و درسى در سطح خرد و كلان، بازنخرى حر اهداف و تعاريف آنها و... توجه شده است. اما از آتجايى كه اين

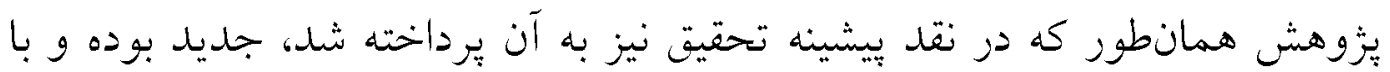
زويكرخ كيفي متفاوتى به اين مسثله نخريسته، و نتايج آن متفاوت از تحقيقات يِيشين است، بنابراين بهطور دقيق نمىتوان كفت كه نتايج اين اهداف با يافتههاى تحقيقات

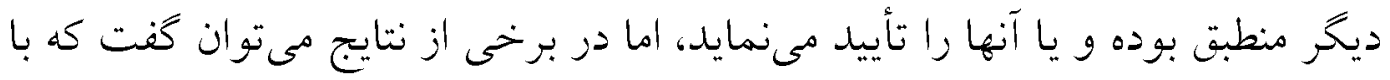
بعضى از يافتههاى ديخر يزوهشخران همسو مىباشد. از جمله اين موازد مىتوان به

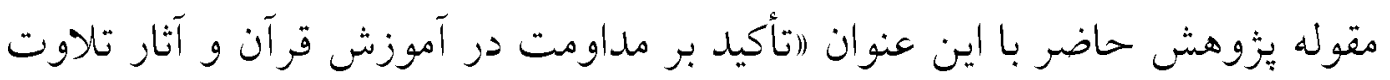

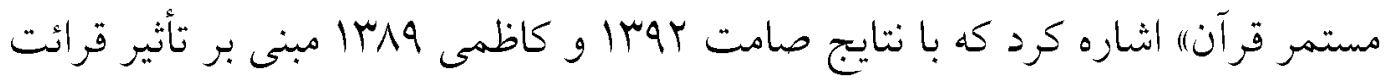
قرآنكريم بر توانايى خوانلن، همسويى است. همتجنين افزايش استماع تلاوت زيبا و

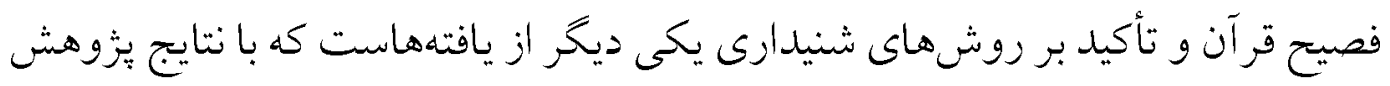

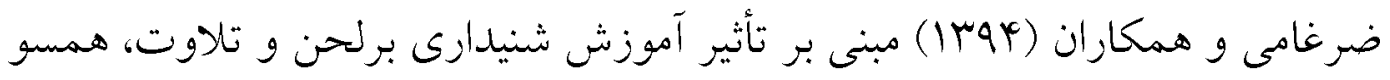

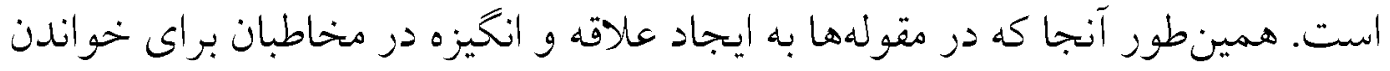

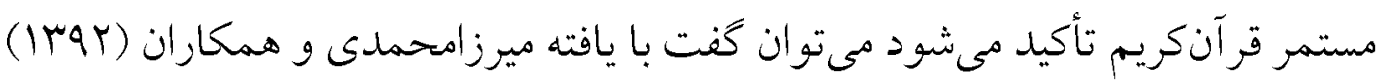
و حسين خانى (1/1|) همسور است. توجه بـ تفاوت فردى دانش آموزان مقوله ايست كه با ياقته صفرزايى (TMr) منطبق است. ايجاد ثنوع در شيوههاى انتقال آموزهاى

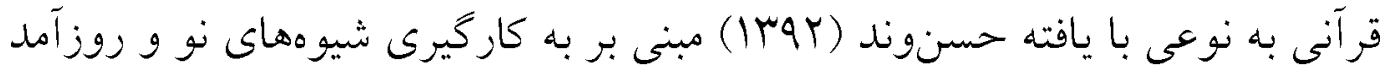

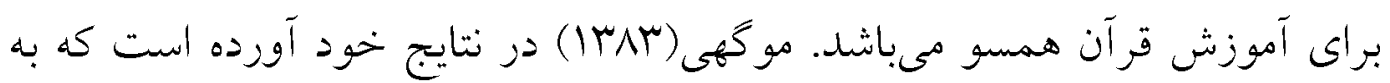
ارزش و اهميّت حفظ قرآن، همينطور اهداف آن بايد توجه داشت، نكتهاى كه در 
نقش معلم در آموزش قرآن و يا مربيّان برورشى نكتهُ ديخرى است كه ير يافتههاى

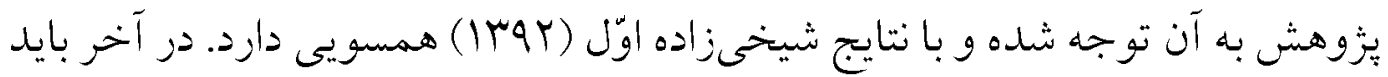

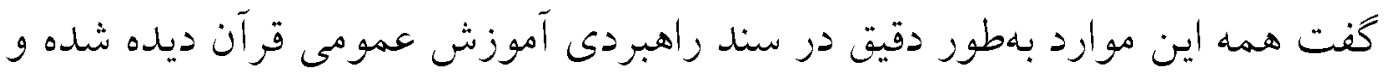

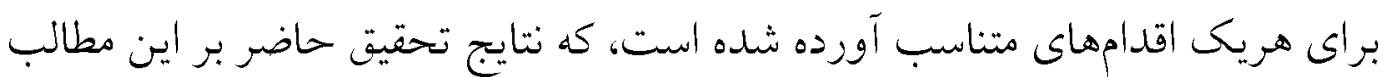

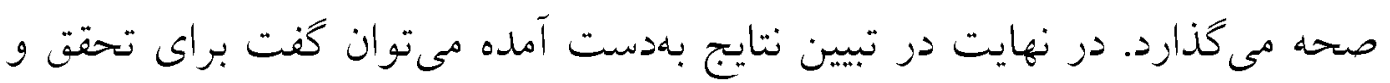

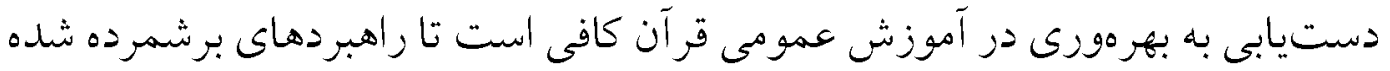

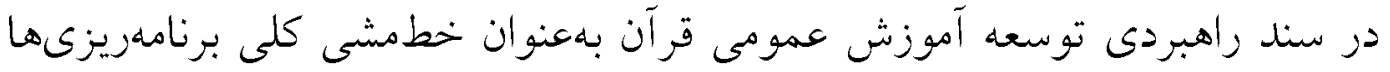

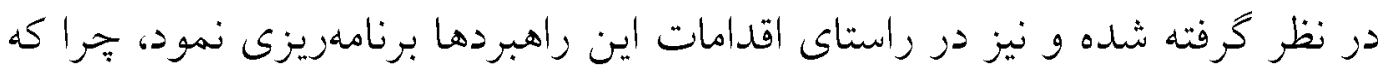

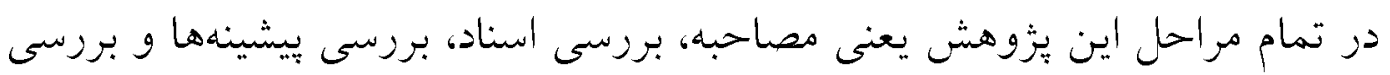

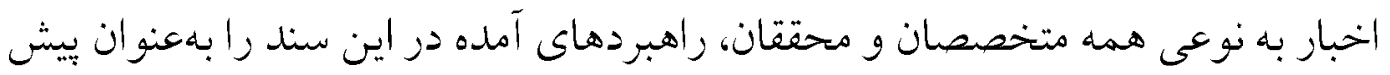

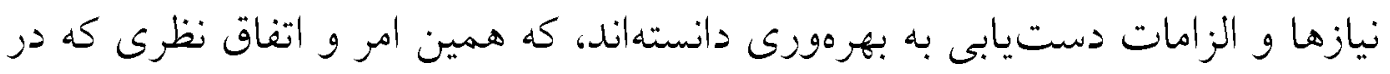

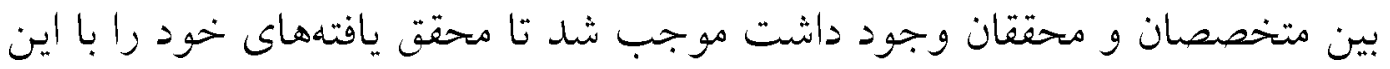

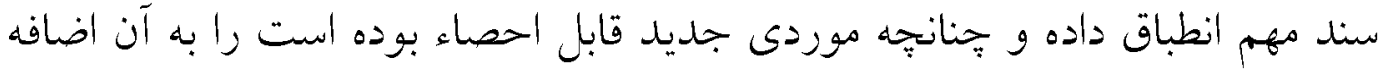

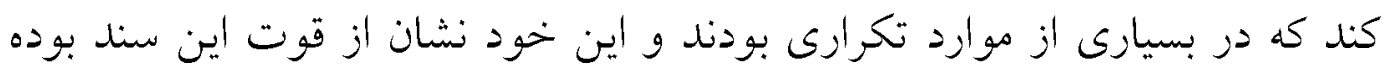

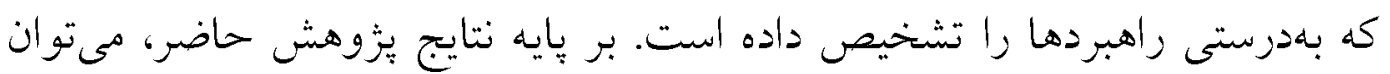

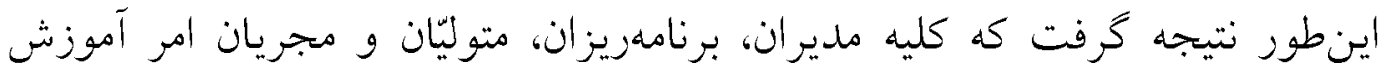

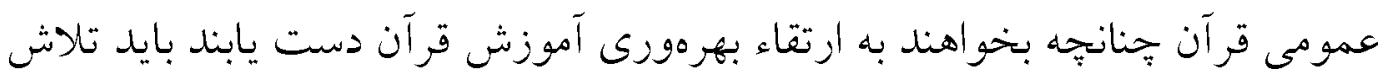

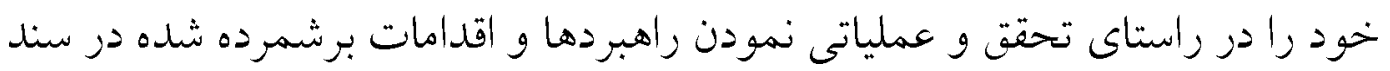

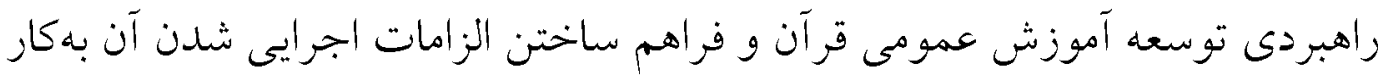

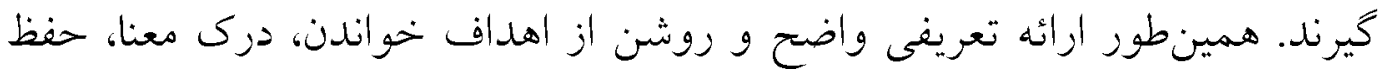

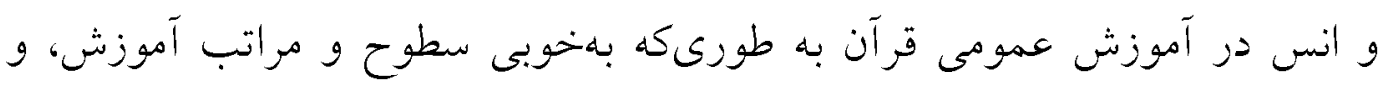

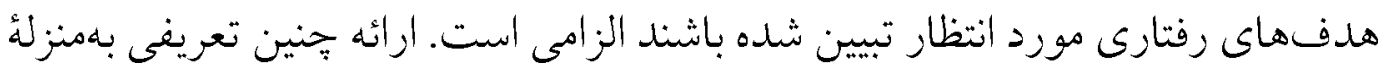

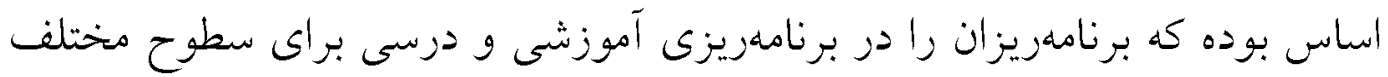

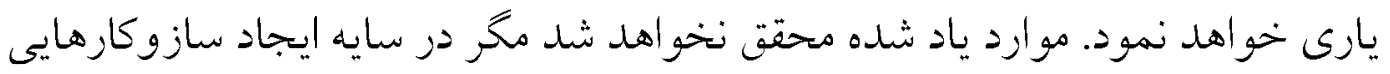

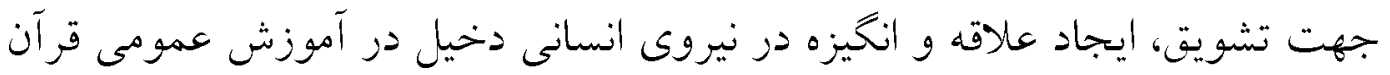

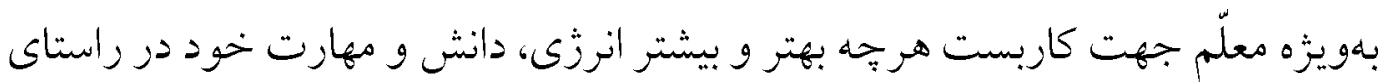
آموزش عمومى قرآن. 


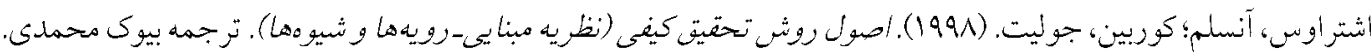

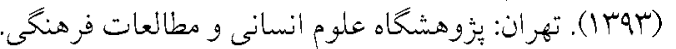

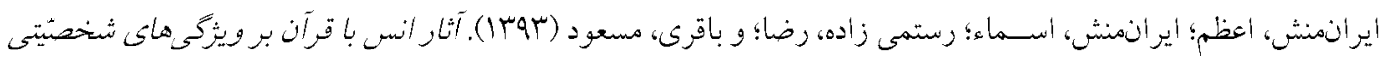

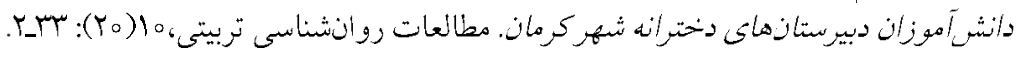

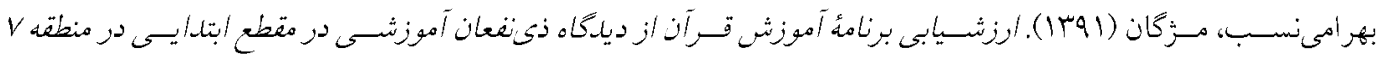

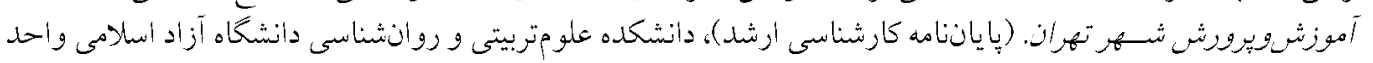
كرمسار.

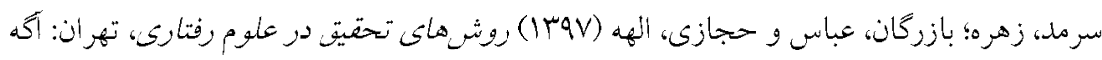

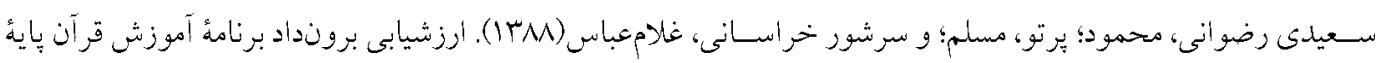

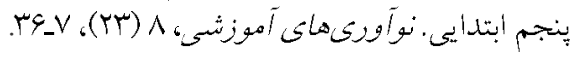

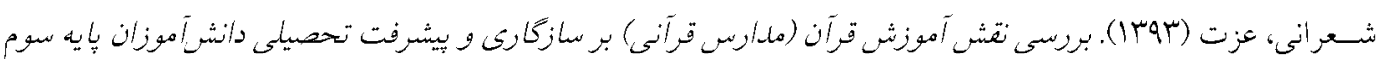

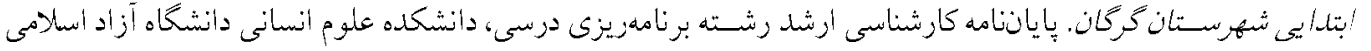
واحد آزايشهر.

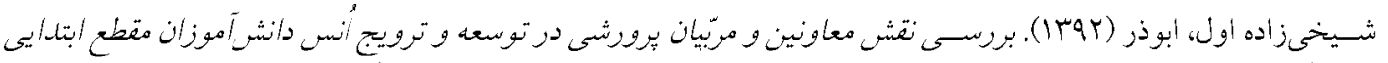

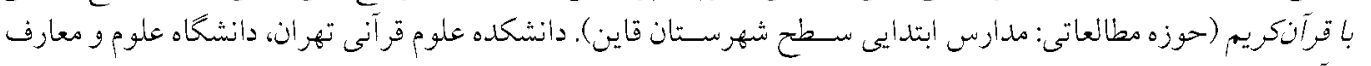
قَرآنكريم

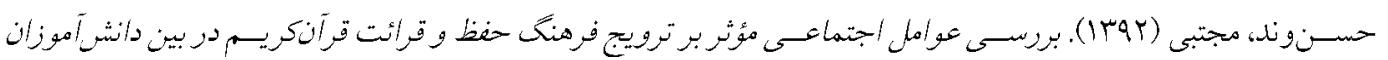

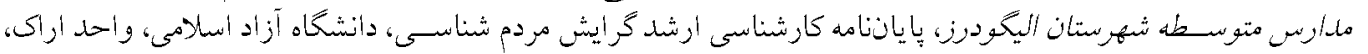

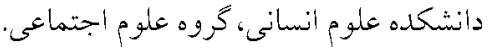

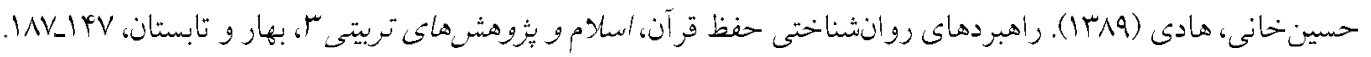

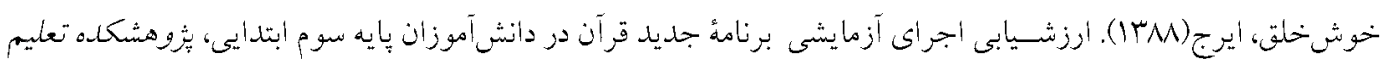
وتربيت.

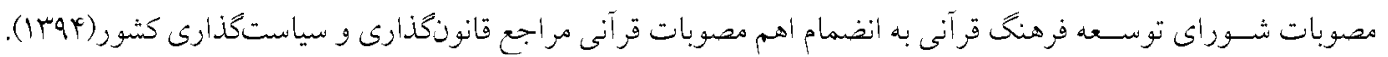

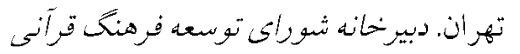

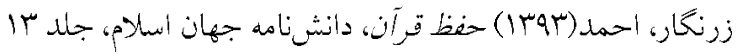

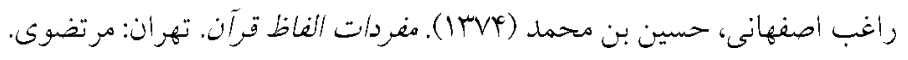

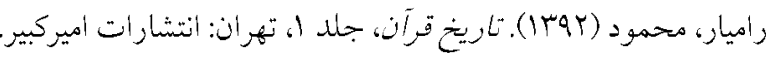

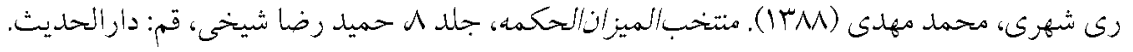

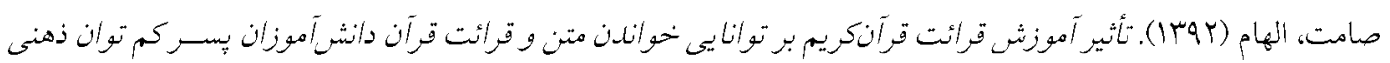

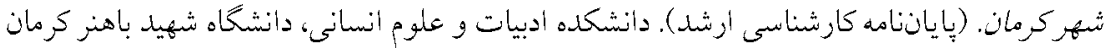

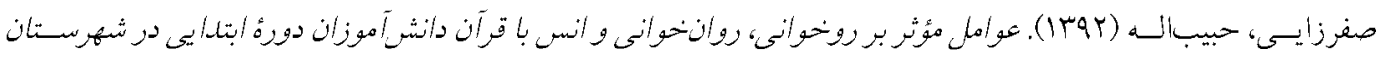

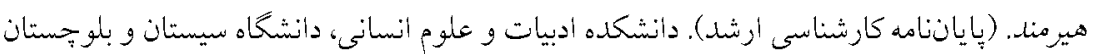

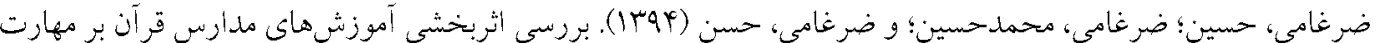

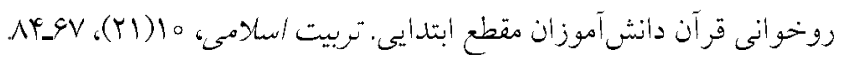




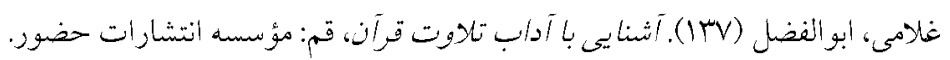

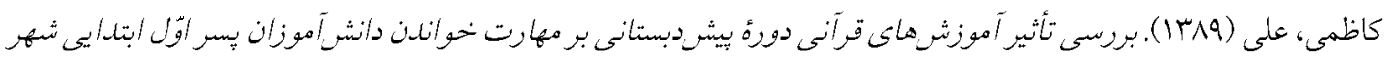

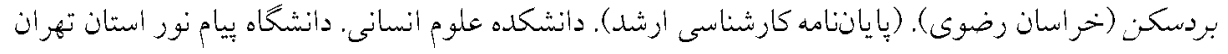

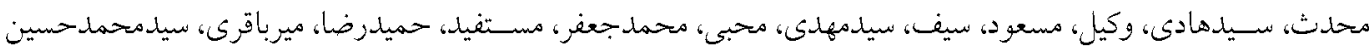

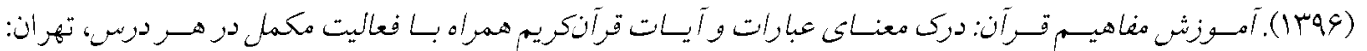

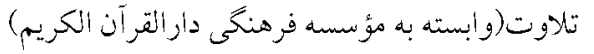

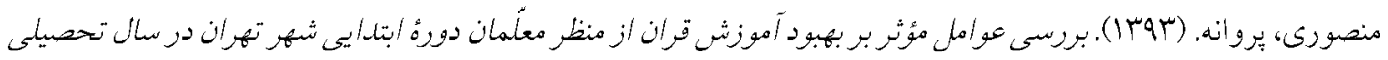

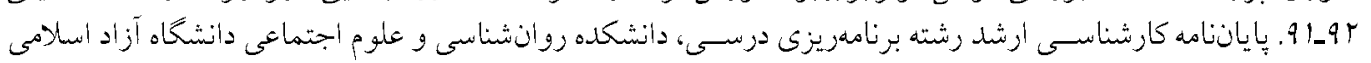

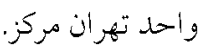

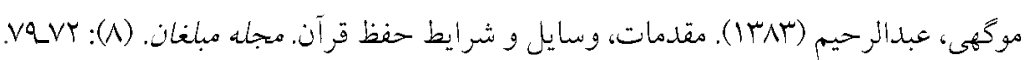

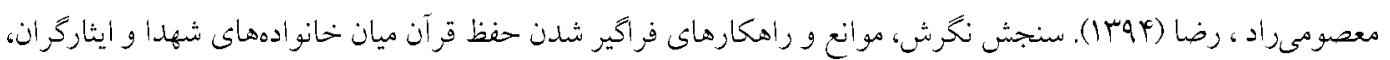

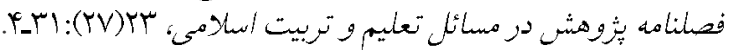

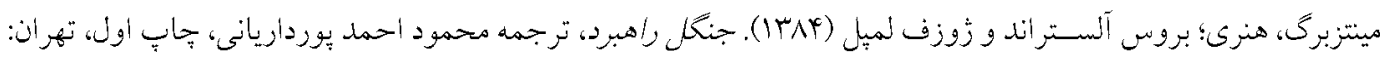
انتشارات برديس.

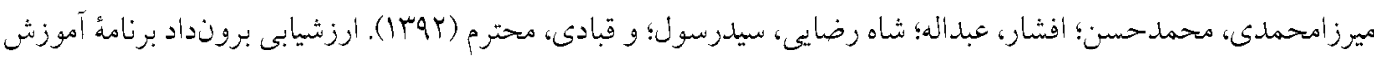
قرآن بائه هنجم أبتدائي در سال تحصيلى

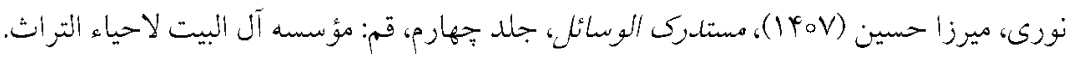

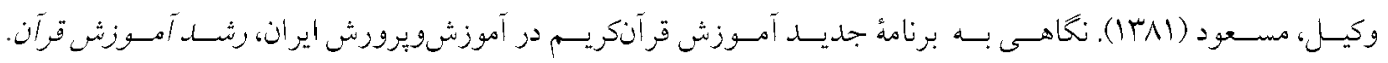

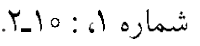

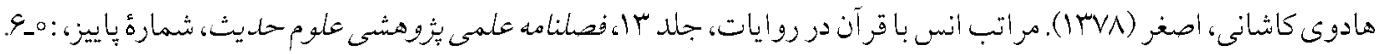
Bailey, K. (2008). Methods of social research. Simon and Schuster. 